\title{
Three Novel Types of Voltage-Dependent Calcium Channels in Rat Cerebellar Neurons
}

\author{
Lia Forti, ${ }^{a}$ Angelita Tottene, Alessandra Moretti, and Daniela Pietrobon \\ Department of Biomedical Sciences, C.N.R. Center of Mitochondrial Physiology, University of Padova, 35131 Padova, Italy
}

\begin{abstract}
With the aim of characterizing the functional and pharmacological properties of the different voltage-dependent $\mathrm{Ca}^{2+}$ channels expressed in a given type of CNS neuron, we obtained single $\mathrm{Ca}^{2+}$ channel recordings from rat cerebellar granule cells in primary culture. Our data show that three novel classes of voltage-dependent $\mathrm{Ca}^{2+}$ channels are coexpressed in cerebellar granule cells. They are pharmacologically distinct from dihydropyridine-sensitive L-type and $\omega$-conotoxin-sensitive $\mathrm{N}$-type channels, and their functional properties are different from those of P-and T-type channels. The three novel 21 pS G1-, 15 pS G2-, and 20 pS G3-type $\mathrm{Ca}^{2+}$ channels have similar inactivation properties. They show complete steady-state inactivation at $-\mathbf{4 0} \mathrm{mV}$ and their single-channel average currents have both sustained and decaying components. They differ in activation threshold $(-40$ $\mathrm{mV}$ for G2, $-30 \mathrm{mV}$ for $\mathrm{G} 3$, and $-10 \mathrm{mV}$ for $\mathrm{G1}$, with $90 \mathrm{~mm}$ $\mathrm{Ba}^{2+}$ as charge carrier), mean open time (1.2 msec for G2, $1 \mathrm{msec}$ for G3, $0.8 \mathrm{msec}$ for G1), and single-channel currents (at $0 \mathrm{mV}: 0.5 \mathrm{pA}$ for G2, $0.8 \mathrm{pA}$ for G3, and 1.4 pA for G1). Together with the previously characterized multiple L-type $\mathrm{Ca}^{2+}$ channels (Forti and Pietrobon, 1993), G1-, G2-, and G3type channels constitute the large majority of $\mathrm{Ca}^{2+}$ channels of cerebellar granule cells in culture. The low activation threshold of G2-type channels and their inactivation properties suggest that they might be native counterparts of the recently expressed rat brain clone rbE-II (Soong et al., 1993).

[Key words: calcium channel, cerebellum, patch clamp, conotoxin, dihydropyridine, granule neuron]
\end{abstract}

Voltage-dependent calcium channels mediate $\mathrm{Ca}^{2+}$ influx into neurons that is crucial for many processes in the brain including dendritic spiking, patterning of neuronal firing, neurotransmitter release, synaptic plasticity, gene expression, and cell death (Llinas, 1988; Sheng and Greenberg, 1990; Weiss et al., 1990; Hille, 1992; Johnston et al., 1992; Kullmann et al., 1992). Many types of calcium channels exist in mammalian brains, where they are probably selectively involved in different neuronal

\footnotetext{
Received Oct. 25, 1993; revised Feb. 7, 1994; accepted Feb. 24, 1994.

We thank Drs. C. Fasolato, T. Pozzan, and M. Zoratti for critically reading the manuscript, and Dr. G. F. Azzone for encouragement and support. This work was supported in part by grants from the Italian Research Council (C.N.R.) Target Project "Aging," and from Telethon (n. 392) to D.P., by a grant from Fidia (Abano Terme, Italy) to D.P. and L.F., and by a fellowship from the International School of Advanced Studies (Trieste, Italy) to L.F., and is in partial fulfillment of the Ph.D. programs of the University of Padova in "Molecular and Cellular Biology and Pathology" by A.T. and in "Pharmacology and Toxicology" by A.M.

Correspondence should be addressed to Daniela Pietrobon, Department of Biomedical Sciences, Via Trieste 75, 35131 Padova, Italy.

-Present address: DIBIT-Scientific Institute San Raffaele, Milano, Italy.

Copyright (C) 1994 Society for Neuroscience $0270-6474 / 94 / 145243-14 \$ 05.00 / 0$
}

functions. On the basis of the threshold voltage for activation, they have been divided in low-threshold-activated (LVA or T-type) $\mathrm{Ca}^{2+}$ channels and high-threshold-activated (HVA) $\mathrm{Ca}^{2+}$ channels (Bean, 1989; Hess, 1990; Swandulla et al., 1991). According to pharmacological criteria, $\mathrm{HVA} \mathrm{Ca}^{2+}$ channels have been classified as L-type channels sensitive to dihydropyridines (DHPs), N-type channels irreversibly blocked by $\omega$-conotoxin GVIA ( $\omega$-CgTx), and funnel toxin (FTX)-sensitive P-type channels selectively blocked by $\omega$-Aga-IVA (Nowycky et al., 1985; Sher and Clementi, 1991; Tsien et al., 1991; Bertolino and Llinas, 1992; Mintz et al., 1992a,b; Usowicz et al., 1992). An additional component of $\mathrm{HVA} \mathrm{Ca}^{2+}$ current, resistant to L-, N-, and P-type-specific inhibitors, has been detected in many CNS neurons (Mintz et al., 1992b).

Although most brain $\mathrm{Ca}^{2+}$ channels have not been fully characterized biochemically in terms of their subunit composition, they are multisubunit structures composed of $\alpha_{1}, \alpha_{2} \delta, \beta$, and perhaps additional subunits (Ahlijanian et al., 1991; McEnery et al., 1991; Sakamoto and Campbell, 1991; Witcher et al., 1993). Cloning studies have shown that in the brain at least five different genes encode different $\mathrm{Ca}^{2+}$ channel $\alpha_{1}$ subunits $\left(\alpha_{1}-\mathrm{A}\right.$, $-B,-C,-D,-E)$, and that further molecular diversity is created by the existence of multiple isoforms for each $\alpha_{1}$ subunit (Snutch et al., 1990, 1991; Hui et al., 1991; Mori et al., 1991; Starr et al., 1991; Dubel et al., 1992; Niidome et al., 1992; Williams et al., 1992a,b; Soong et al., 1993). Heterologous expression studies have shown that the $\alpha_{1}$ subunits are the voltage-sensitive pore-forming components of the $\mathrm{Ca}^{2+}$ channel complexes responsible for pharmacological sensitivity, and that both $\alpha_{1}-\mathrm{C}$ and $\alpha_{1}-\mathrm{D}$ encode L-type $\mathrm{Ca}^{2+}$ channels, while $\alpha_{1}$-B encodes N-type channels (Mikami et al., 1989; Biel et al., 1990; Williams et al., 1992a,b; Fujita et al., 1993). While it has been established that $\alpha_{1}-\mathrm{A}$ and $\alpha_{1}$-E encode $\mathrm{Ca}^{2+}$ channels resistant to both DHPs and $\omega$-CgTx (Mori et al., 1991; Fournier et al., 1993; Sather et al., 1993; Soong et al., 1993), a more precise correlation with already characterized native $\mathrm{Ca}^{2+}$ channels remains uncertain. Although, given its high level of expression in cerebellum, $\alpha_{1}-\mathrm{A}$ has been assumed to encode P-type channels, the channels produced by $\alpha_{1}$-A when expressed in oocytes have different functional properties and are far less sensitive to block by $\omega$-AgaIVA than P-type channels of Purkinje cells (Mori et al., 1991; Sather et al., 1993; but cf. Fournier et al., 1993). Very recently, the $\mathrm{Ca}^{2+}$ current resistant to DHPs, $\omega$-CgTx-GVIA, and low concentrations of $\omega$-Aga-IVA of cerebellar granule cells has been pharmacologically separated into two components, one sensitive ( $Q$ type) and one insensitive ( $R$ type) to $\omega$-CTx-MVIIC (Hillyard et al., 1992), and it has been suggested that $\alpha_{1}-\mathrm{A}$ and $\alpha_{1}$-E encode Q-type and R-type channels, respectively (Ellinor et al., 1993; Randall et al., 1993; Zhang et al., 1993). 
Further molecular diversity of brain $\mathrm{Ca}^{2+}$ channels can be generated by different combinations of the various subunits that form the channel complex. At least four different genes (producing various isoforms) cncodc multiple $\beta$ subunits, and different $\beta$ subunits have been shown to modulate differentially the kinetic properties of the $\mathrm{Ca}^{2+}$ current generated by a given $\alpha_{1}$ subunit (Singer et al., 1991; Hullin et al., 1992; Perez-Reyes et al., 1992; Castellano et al., 1993; Ellinor et al., 1993; Sather et al., 1993).

Considering the different genes for $\alpha_{1}$ and $\beta$ subunits, the different splice variants for each subunit, and the many possible subunit combinations, a functional diversity of brain $\mathrm{Ca}^{2+}$ channels much wider than the established pharmacological diversity can be expected in native neuronal membranes. However, the functional consequences of the large molecular diversity of $\mathrm{Ca}^{2+}$ channels in CNS neurons remain largely unknown. N-type currents with different (in particular, inactivation) properties have been reported in different mammalian neurons (Hirning et al., 1988; Plummer et al., 1989; Carbone et al., 1990; Regan et al., 1991; Kasai and Neher, 1992), and recent single-channel recordings have shown that L-type channels with very different voltage-dependent properties coexist in rat cerebellar granule cells (Forti and Pietrobon, 1993). On the other hand, the functional properties of P-type channels have been studied in detail only in cerebellar Purkinje cells (Regan, 1991; Usowicz et al., 1992) and little is known on the voltage-dependent properties of the $\mathrm{Ca}^{2+}$ channels resistant to inhibitors of L-, N-, and P-type currents.

With the aim of characterizing the functional and pharmacological properties of all the different voltage-dependent $\mathrm{Ca}^{2+}$ channels expressed in a given type of CNS neuron, we obtained single $\mathrm{Ca}^{2+}$ channel recordings from rat cerebellar granule cells in primary culture. In this article we report the characterization of the elementary functional properties of three different types of voltage-dependent $\mathrm{Ca}^{2+}$ channels, all resistant to both DHPs and $\omega-\mathrm{CgTx}$. Together with the previously characterized multiple L-type channels (Forti and Pietrobon, 1993), they are the most abundant $\mathrm{Ca}^{2+}$ channels in cerebellar granule cell bodies. $\mathrm{Ca}^{2+}$ channels with similar functional and pharmacological properties have not been previously reported in native neuronal membranes.

\section{Materials and Methods}

Cell culture. Cerebellar granule cells were grown in primary culture after enzymatic and mechanical dissociation from 7-8-d-old Wistar rats according to the procedure of Levi et al. (1984). The cells were plated on poly-L-lysine-coated glass coverslips and kept in Basal Eagle's medium supplemented with $10 \%$ fetal calf serum, $25 \mathrm{~mm} \mathrm{KCl}, 2 \mathrm{~mm}$ glutamine, and $60 \mu \mathrm{g} / \mathrm{ml}$ gentamicin. Cytosine arabinoside $(10 \mu \mathrm{M})$ was added to the culture $18 \mathrm{hr}$ after plating to inhibit the proliferation of non-neuronal cells. Granule cells were the large majority of the cells in the cultures, and were morphologically identified by their oval or round cell body, small size, and bipolar neurites. Experiments were performed on granule cells grown from 2 to $11 \mathrm{~d}$ in vitro.

Patch-clamp recordings and data analysis. Single-channel patch-clamp recordings followed standard techniques (Hamill et al., 1981). All recordings were obtained in the cell-attached configuration. Single-channel currents were recorded with a DAGAN 3900 patch-clamp amplifier, low-pass filtered at $1 \mathrm{kHz}(-3 \mathrm{~dB} ; 8$-pole Bessel filter), sampled at 5 $\mathrm{kHz}$, and stored for later analysis on a PDP-11/73 computer. Depolarizing test pulses of $720 \mathrm{msec}$ duration were delivered every $4 \mathrm{sec}$, from variable holding potentials.

Linear leak and capacitative currents were digitally subtracted from all records used for analysis. A channel opening or closure was detected when more than one sampling point crossed a discriminator line at $50 \%$ of the elementary current. Histograms of open and closed times were fitted with sums of decaying exponentials. The best fit was determined by maximum likelihood maximization (Colquhoun and Sigworth, 1983) and the best minimum number of exponential components was determined by the maximum likelihood ratio test (Rao, 1973; Horn and Lange, 1983). Log binning and fitting of the binned distributions were done as described by McManus et al. (1987) and Sigworth and Sine (1987). In log-log plots of fitted open or closed time distributions, the presence of an exponential component is signaled by a bump in the distribution of data. The dark solid line in each log-log plot is the bestfitting sum of decaying exponential components. Each exponential component is shown as a dotted line fitting the corresponding bump. Average open time duration, $t_{0}$, was calculated as the arithmetic average of all open times measured in each sweep at a given voltage. Current amplitude histograms were obtained from the data directly, with bin width equal to our maximal resolution (323.6 points/pA). For display, each histogram was normalized to the value of the zero current peak. Open probability, $p_{o}$, was computed by measuring the average current $\langle I\rangle$ in a given single-channel current and dividing it by the unitary singlechannel current $i$. To obtain activation curves, $p_{o}$ values were calculated by averaging the open probabilities measured in each sweep at a given voltage only in segments with single-channel activity. In this case the values of $p_{o}$ reflect the voltage-dependent equilibrium between shortlived open and closed states in the activation pathway, and therefore give an activation threshold that does not exactly match that obtainable from whole-cell recordings in which other voltage-dependent nonconducting states are important. Open-channel current amplitudes for $i-V$ relations were measured by manually fitting cursors to well-resolved channel openings. Values at each voltage are averages of many measurements and standard errors are smaller than the symbol size.

The pipette solution contained either $\mathrm{BaCl}_{2}, 90 \mathrm{~mm} ; \mathrm{TEA}-\mathrm{Cl}, 10 \mathrm{~mm}$; $\mathrm{CsCl}, 15 \mathrm{~mm}$; HEPES, $10 \mathrm{~mm}$ (pH 7.4 with TEA-OH); or sometimes $\mathrm{CsCl}$ was absent and the TEA-Cl concentration was changed to $30 \mathrm{~mm}$. The bath solution was either K-aspartate, $140 \mathrm{~mm}$; EGTA, $5 \mathrm{~mm}$; L-glucose, $35 \mathrm{~mm}$; HEPES, $10 \mathrm{~mm}$ (pH 7.4 with $\mathrm{KOH}$ ); or K-aspartate was substituted with the same concentration of $\mathrm{K}$-gluconate. The high-potassium bath solution was used to zero the membrane potential outside the patch. The DHP agonist (+)-(S)-202-791 (gift of Dr. Hof, Sandoz Co., Basel, Switzerland) was added during experiments by gravity perfusion or added to the bath before recording. $\omega$-CgTx-GVIA (Peninsula Laboratories, Belmont, CA) was usually added to both the pipette solution and the divalent-free bath solution. Cells were always incubated for at least $10 \mathrm{~min}$ in the presence of toxin before recording. Stock solutions: $3 \mathrm{~mm}(+)-(S)-202-791$ in $95 \%$ ethanol and $128 \mu \mathrm{M} \omega-\mathrm{CgTx}$ in distilled water, both stored at $-20^{\circ} \mathrm{C}$.

For whole-cell recordings cells were placed into a recording chamber with Tyrode's solution. After attainment of the whole-cell configuration cells were perfused with the external recording solution containing 5 $\mathrm{mM} \mathrm{BaCl}_{2}, 135 \mathrm{~mm}$ TEA-Cl, and $10 \mathrm{~mm}$ HEPES (adjusted to $\mathrm{pH} 7.4$ with TEA-OH). Internal solution contained $100 \mathrm{mM} \mathrm{Cs}$-methanesulfonate, $5 \mathrm{~mm} \mathrm{MgCl}$, $30 \mathrm{~mm}$ HEPES, $10 \mathrm{~mm}$ EGTA, $4 \mathrm{~mm}$ ATP, 0.5 mM GTP, and $1 \mathrm{mM}$ cAMP (adjusted to pH 7.4 with $\mathrm{CsOH}$ ). The perfusion system consisted of six microcapillary teflon tubes glued together and placed inside a standard plastic pipette (Gilson) at about 12 $\mathrm{mm}$ from the tip (about $1.2 \mathrm{~mm}$ diameter), which was cut to have a flute beak shape, and positioned close to the cell. The tubes were fed by gravity from reservoirs containing external solution with or without $\omega$-CgTx (and/or $\mathrm{Cd}^{2+}$ ). Switching between different solutions was controlled by solenoid valves. Delay time for complete solution change was less than $8 \mathrm{sec}$. Calcium currents were corrected for leak and capacitative currents by subtraction of an appropriately scaled current elicited by a $10 \mathrm{mV}$ hyperpolarization. Isolated cells with short processes were chosen for recording. The experiment was discarded if cells showed signs of inadequate space clamping such as notch-like current discontinuities or slow tails not fully inhibited by nimodipine (Pietrobon and Forti, 1993). Experiments were performed at room temperature $\left(21-25^{\circ} \mathrm{C}\right)$.

\section{Results}

Cell-attached patch-clamp recordings from rat cerebellar granule cells in primary culture show that, in addition to functionally different L-type channcls (Forti and Pictrobon, 1993), ccrcbcllar granule cells express many functionally different DHP-insensitive channels. Three types of DHP-insensitive channels were observed sufficiently often to allow a complete characterization 
of their main biophysical properties. Since these three types of calcium channels turned out to be insensitive also to $\omega-\mathrm{CgTx}$ GVIA (see Fig. 7) and to have functional properties different from those reported for P-type channcls in Purkinje cells (Usowicz et al., 1992), we have called them G1, G2, and G3 (where $\mathrm{G}$ stands for granule cell, and 1, 2, and 3 refer to the order of frequency with which they were observed).

\section{Gl-type calcium channels}

Figure $1 a$ shows the unitary activity of a single G1-type calcium channel in response to 720 -msec-long test depolarizations to 0 , 10 , and $20 \mathrm{mV}$, and the corresponding current amplitude histograms. The channel open probability, $p_{o}$, increased eight times (from 0.027 to 0.218 ) when the membrane potential, $V$, was changed from 0 to $+20 \mathrm{mV}$. The activation curve in Figure $1 b$, obtained by averaging the open probability of single G1 channels from several patches, shows that their threshold for activation is around $-10 \mathrm{mV}$, while their probability of opening approaches its maximum value at $+30 \mathrm{mV}$. Figure $1 a$ and the corresponding open time distribution in Figure $1 d$ (see legend) show that G1-type channels are characterized by very brief openings, most of which were incompletely resolved at the bandwidth of our recording system, as shown by the poorly resolved open-channel peak in the amplitude histograms. We obtained average open time durations, $t_{o}$, of $0.75 \pm 0.04 \mathrm{msec}( \pm$ SEM; $n=4)$ at $+10 \mathrm{mV}, 0.78 \pm 0.02 \mathrm{msec}(n=7)$ at $+20 \mathrm{mV}$, and $0.84 \pm 0.03 \mathrm{msec}(n=4)$ at $+30 \mathrm{mV} . t_{o}$ appeared to be not significantly voltage dependent in the range of $0-30 \mathrm{mV}$.

The unitary current-voltage relation in Figure $1 c$, obtained by averaging the unitary current amplitudes of well-resolved openings of G1-type channels from many patches, has a slope conductance of $20.1 \mathrm{pS}$. The average of the single-channel conductances obtained from any individual patch was $21.2 \pm 0.3$ $\mathrm{pS}(n=8$, with a single-channel current, $i=1.37 \pm 0.03 \mathrm{pA}$ at $0 \mathrm{mV}$ ).

Figure 2 shows the inactivation properties of G1-type calcium channels. The single-channel current traces at $+20 \mathrm{mV}$ and the ensemble average current in Figure $2 a$ are from a patch containing a single G1-type channel (as judged by the lack of overlapping events for the entire 29 min duration of the experiment). Figure $2 a$ shows that, during 720 -msec-long depolarizations to $+20 \mathrm{mV}$, the same $\mathrm{Gl}$ channel can give rise to both inactivating and noninactivating behavior; as a result, the ensemble average of unitary currents had both a sustained and an inactivating component. The inactivating component amounted to $42 \%$ of the peak current and decayed with a time constant of $128 \mathrm{msec}$.

Figure $2 b$ shows that when the holding potential between successive depolarizations to $+20 \mathrm{mV}$ was changed from -80 $\mathrm{mV}$ to $-40 \mathrm{mV}$, the G1-type calcium channel did not open upon depolarization. On the other hand, the overall open probability of the channel increased only very little when the holding potential was changed from -80 to $-100 \mathrm{mV}$. Steady-state inactivation of Gl-type calcium channels then occurs at relatively negative voltages (over the range of -80 to $-40 \mathrm{mV}$ ). Figure $2 b$ shows that even at holding potentials of -80 to -100 $\mathrm{mV}$ there were periods in which the G1-type calcium channel did not open upon depolarization. The average fraction of sweeps without activity (nulls) in six single-channel patches was $48 \pm$ $4 \%$ (for test depolarizations from 0 to $+20 \mathrm{mV}$ and holding potentials from -80 to $-100 \mathrm{mV}$ ).

G1-type calcium channels were observed in $32 \%$ of patches from neurons kept in culture for 6-11 d (37 of 116 patches), and only in $9.5 \%$ of patches ( 6 of 63 patches) from neurons kept in culture for $1-5 \mathrm{~d}$. Since all patches where identification of channel type was uncertain (i.e., almost all multichannel patches) were excluded from the statistics, while patches without activity were included, the calculated frequency of observation represents a lower estimate, especially in the case of 6-11-d-old neurons.

A minority of cerebellar calcium channels that we have classified as G1 type had properties somehow different from those just described.

Of a total of 43 patches with G1-type channels, in five we observed calcium channels with inactivation properties like those in Figure 2 and threshold for activation around $-10 \mathrm{mV}$ as in Figure $1 a$, but with about 1.5 times higher $p_{o}$ at each $V$, higher mean open time $\left(t_{o}=1.03 \pm 0.08 \mathrm{msec}, n=3\right.$, at $\left.+20 \mathrm{mV}\right)$, and shorter closed times (time constants of the two exponential components best fitting the closed time distributions: $0.8 \pm 0.11$ and $2.35 \pm 0.62 \mathrm{msec}$ at $+20 \mathrm{mV}$; see Fig. $1 d$ legend). Moreover, these G1-type channels had slightly but significantly higher single-channel conductance $(g-24.7 \pm 0.55 \mathrm{pS}, n=3)$ and unitary currents at each $V(i=1.52 \pm 0.05 \mathrm{pA}, n=4$, at $0 \mathrm{mV}]$.

In three patches in the presence of DHP agonist $(+)-(S)$-202791 we observed calcium channels with activation properties and unitary currents like those in Figure 1, but with steady-state inactivation occurring at more positive voltages than for typical G1-type channels. In one case (cell C14I) the single channel in the patch did not inactivate during $5 \mathrm{~min}$ of successive depolarizations separated by $4 \mathrm{sec}$ at a holding potential of $-30 \mathrm{mV}$ (not shown). The number of null sweeps were very few (only $9 \%$ ) at the holding potential of $-90 \mathrm{mV}$; they increased to $43 \%$ when the holding potential was changed to $-30 \mathrm{mV}$.

The functional differences with respect to typical G1-type $\mathrm{Ca}^{2+}$ channels, observed in the two different minorities of channels just described, can originate either from structural diversity or from modulation of G1-type channels by unidentified cellular processes. Since our data do not allow a discrimination between the two alternative interpretations, the classification of these two minorities of $\mathrm{Ca}^{2+}$ channels into the category of G1-type channels, although rather arbitrary, appears as the most conservative choice for the time being. However, one should bear in mind that future experiments may show that these channels actually constitute two additional classes of $\mathrm{Ca}^{2+}$ channels different from G1 type.

\section{G2-type calcium channels}

Figure $3 a$ shows the unitary activity of a single G2-type calcium channel in response to 720 -msec-long depolarizations to -30 , -20 , and $-10 \mathrm{mV}$, and the corresponding current amplitude histograms. The channel open probability increased six times (from 0.056 to 0.34 ) when $V$ was changed from -30 to -10 $\mathrm{mV}$. The activation curve in Figure $3 b$, obtained by averaging $p_{o}$ of single G2-type channels from several patches, shows that their threshold for activation is around $-40 \mathrm{mV}$, about $30 \mathrm{mV}$ more negative than that of G1-type calcium channels (dashed line). While for G1-type channels there was not much variability in the $p_{o}$ values calculated in individual successive depolarizations at any given $V$ (except for very rare brief periods of much higher $p_{o}$, not shown), a single G2-type channel usually showed some variability in open probability in different depolarizations at the same voltage (e.g., compare higher $p_{o}$ of the second trace with respect to the first trace at -20 and $-10 \mathrm{mV}$ in Fig. $3 a$ : $p_{o}=0.25$ and 0.48 with respect to 0.17 and 0.33 , respectively). 
a

\section{$0 \mathrm{mV}$}

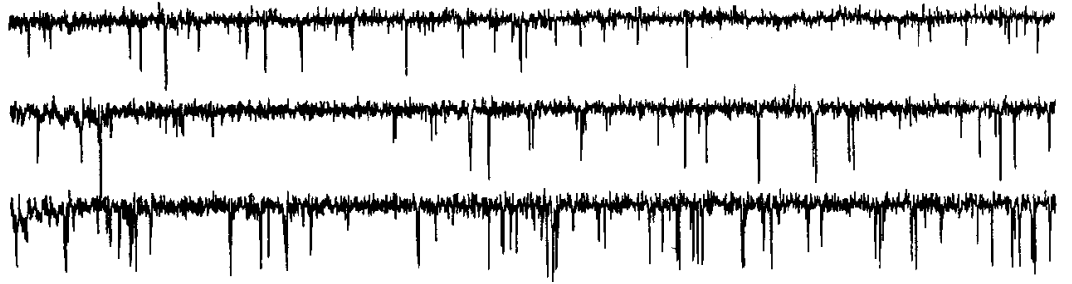

$10 \mathrm{mV}$

(n)
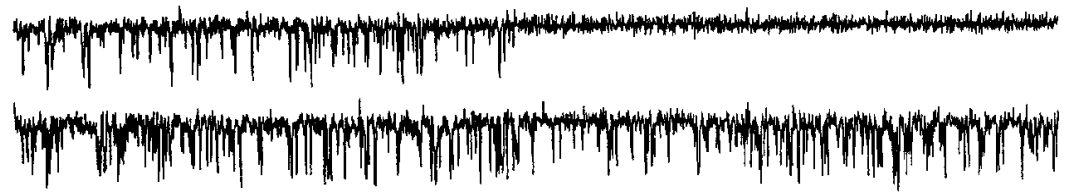

$20 \mathrm{mV}$

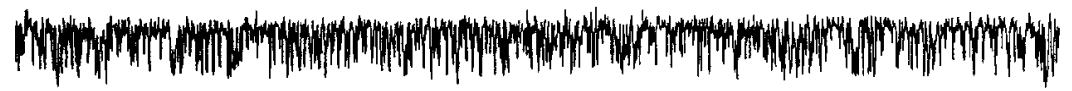

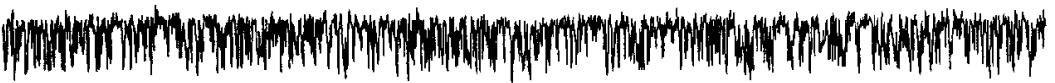

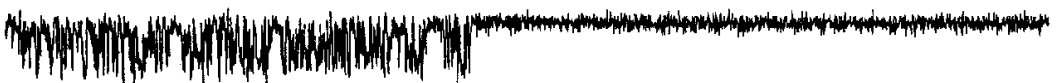

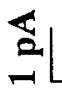

\section{$80 \mathrm{msec}$}

b

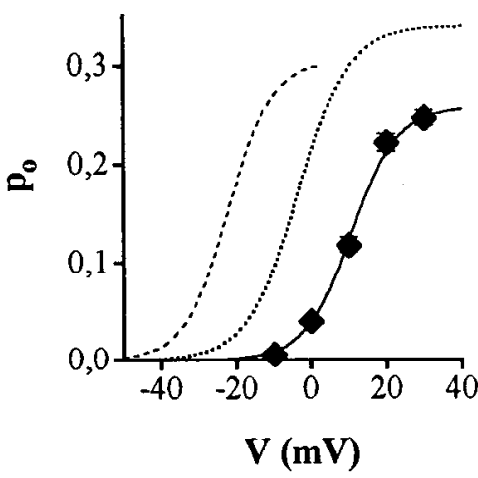

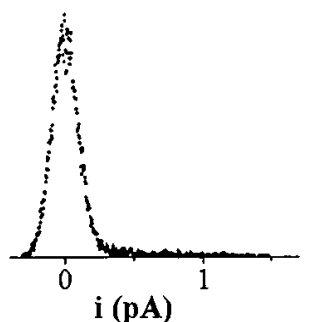
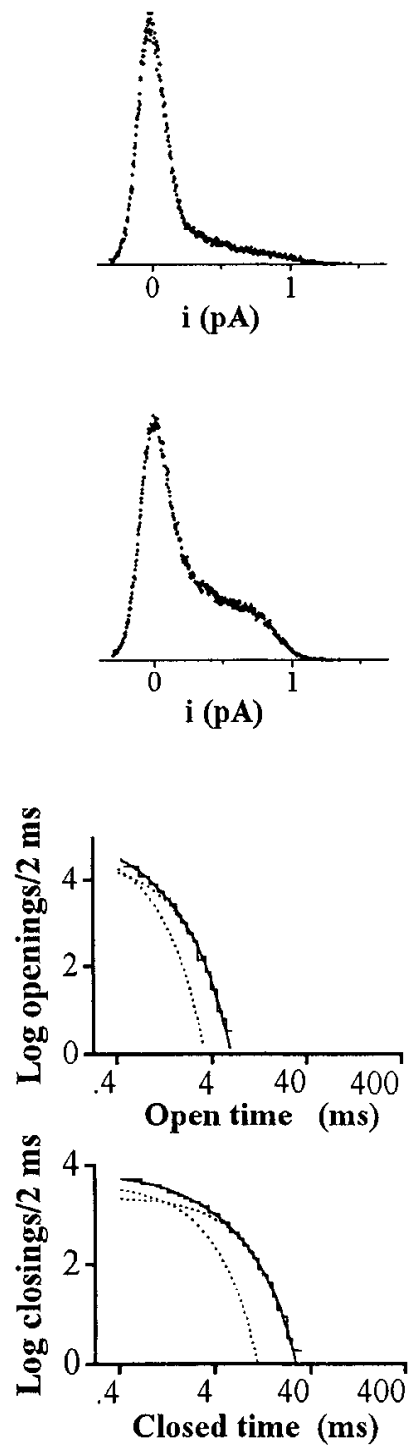

Figure 1. Conductance and activation properties of $\mathrm{Gl}$-type $\mathrm{Ca}^{2+}$ channels in rat cerebellar granule cells. $a$, Cell-attached recordings with 90 mM $\mathrm{Ba}^{2+}$ as charge carrier from a patch containing a single Gl-type channel. Three representative current traces at 0,10 , and $20 \mathrm{mV}$ are shown together with the normalized current amplitude histograms from all traces with activity at each $V$. Depolarizations were $720 \mathrm{msec}$ long and were delivered every $4 \mathrm{sec}$ from holding potentials of $-80 \mathrm{mV}$. Records were sampled and filtered at 5 and $1 \mathrm{kHz}$, respectively. Cell N02B. $b$, Voltage dependence of the open probability, $p_{o}$, of Gl-type $\mathrm{Ca}^{2+}$ channels. Open probability values are averages from different patches $(n=8$ at +10 and $+20 \mathrm{mV} ; n$ $=4$ at $-10,0$, and $+30 \mathrm{mV})$. For each patch, $p_{o}$ values at a given voltage were obtained by averaging the open probabilities measured in each sweep only in segments with activity. The data points are fitted by a Boltzmann distribution of the form $p_{o}=p_{o, \max } \times\left\{1+\exp \left[-\left(V-V_{1 / 2}\right) \times z F /\right.\right.$ $R T]\}^{-1}$, with $z=4.17, V_{1 / 2}=10.5 \mathrm{mV}$, and $p_{o, \max }=0.258$. The dashed and dotted curves are the Boltzmann distributions that fit the voltage dependence of the open probability of G2-type and G3-type calcium channels, respectively. $c$, Unitary current-voltage relation of G1-type calcium channels. Unitary current values are averages from eight different patches (SEs are smaller than the symbol size). For each patch, values of $i$ at a given voltage are averages of many measurements on well-resolved openings. The dashed and dotted lines represent the $i-V$ relations for G2-and G3-type $\mathrm{Ca}^{2+}$ channels. $d$, Log-log plots of the open and closed time distributions of a single G1-type channel. $V=+20 \mathrm{mV}$. The dark solid line 
$\mathbf{a}$

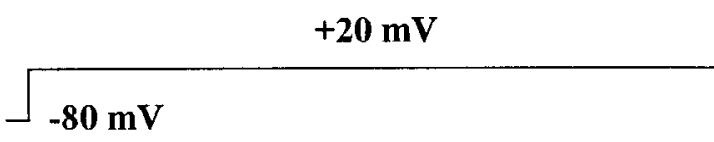

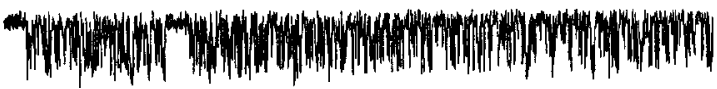
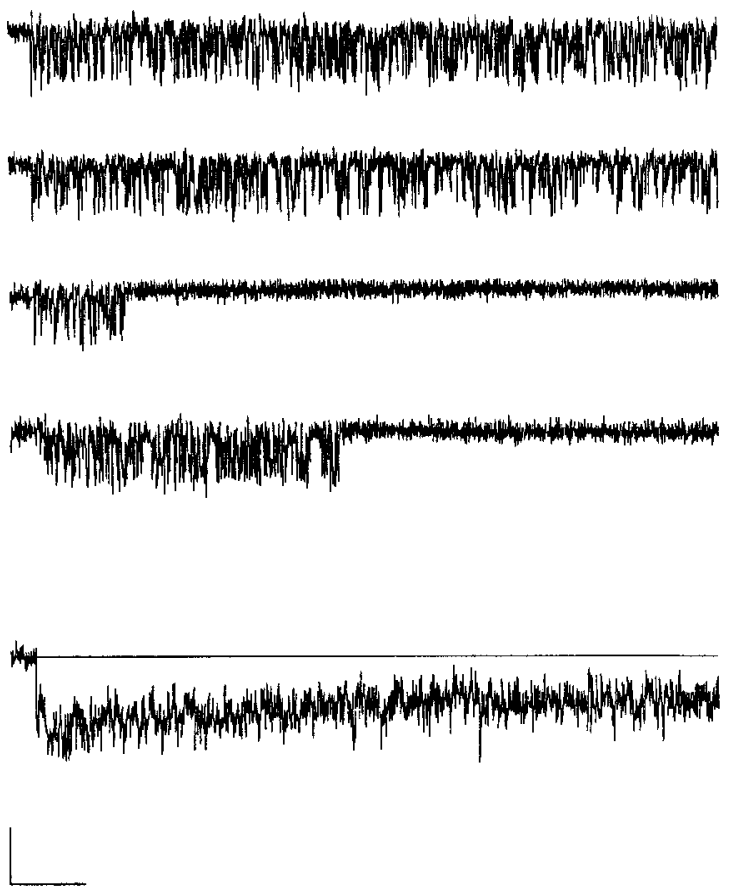

b

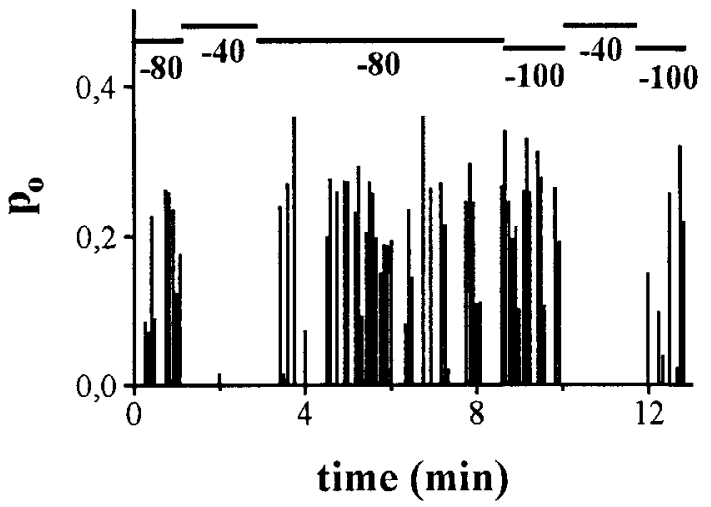

Very rarely, brief periods with much higher $p_{o}$ were observed (not shown).

As evident from the representative traces at -20 and -30 $\mathrm{mV}$, in addition to a prevailing unitary current level, G2-type channels showed brief transitions to a slightly higher current level and also openings to a lower level (e.g., middle trace at $-20 \mathrm{mV}$ ). The $i-V$ plot in Figure $3 c$, obtained by averaging the amplitudes of the prevailing unitary current level of G2-type channels from many patches, has a slope conductance of $15 \mathrm{pS}$. The average of the single-channel conductances obtained from any individual patch was $14.9 \pm 0.8 \mathrm{pS}(n=5$, with a singlechannel current $i=0.54 \pm 0.02 \mathrm{pA}$ at $0 \mathrm{mV}$ ).

As shown by Figurc $3 a$ and the corresponding open timc distribution in Figure $3 d$ (see legend), openings of G2-type channels were longer and better resolved than those of G1-type channels. We obtained average open time durations, $t_{o}$, of $1.27 \pm$ $0.08 \mathrm{msec}(n=4)$ at $-20 \mathrm{mV}, 1.24 \pm 0.06 \mathrm{msec}(n=4)$ at -10 $\mathrm{mV}$, and $1.08 \pm 0.08 \mathrm{msec}(n=4)$ at $0 \mathrm{mV}$.

Figure 4 shows the inactivation properties of 62 -type calcium channels. The single-channel current traces at $-10 \mathrm{mV}$ and the corresponding ensemble average current in Figure $4 a$ are from a patch containing a single G2-type channel (as judged by the lack of overlapping events for the entire $17 \mathrm{~min}$ duration of the experiment). Figure $4 a$ shows that G2-type calcium channels, like Gl-type channels, can give rise both to inactivating and noninactivating behavior. Accordingly, the average current had both a sustained and an inactivating component. The inactivating component decayed with a time constant of $122 \mathrm{msec}$, similar to that obtained for G1-type calcium channels. The inactivating component seemed to increase relative to the sustained component with increasing test pulse voltage (Fig. $4 b$, and see legend).

Figure 2. Inactivation properties of Gl-type $\mathrm{Ca}^{2+}$ channels. $a$, Cellattached recordings with $90 \mathrm{mM} \mathrm{Ba}^{2+}$ as charge carrier from a patch containing a single Gl-type channel. Depolarizations were $720 \mathrm{msec}$ long and were delivered every $4 \mathrm{sec}$ from holding potentials of -80 $\mathrm{mV}$. Records were sampled and filtered at 5 and $1 \mathrm{kHz}$, respectively. Five current traces (calibration: $1 \mathrm{pA}, 80 \mathrm{msec}$ ) are shown together with the cnscmblc average current from all sweeps with activity at $+20 \mathrm{mV}$ ( $n=52$; calibration: $0.175 \mathrm{pA}, 80 \mathrm{msec}$ ). The fraction of inactivating active sweeps was $42 \%$ ( 22 of 52). Cell N02B. The average fraction of inactivating sweeps of G1-type channels in different patches was $34 \pm$ $3 \%(n=4)$ at $+10 \mathrm{mV}$ and $50 \pm 6 \%(n=4)$ at $+20 \mathrm{mV}$. $b$, Holding potential dependence of the open probability of a single G1-type channel. Vertical bars in the $p_{o}$ versus time plot represent the channel open probability in successive depolarizations at $+20 \mathrm{mV}$ delivered every 4 sec. During the experiment the holding potential was changed, as indicated below the horizontal bars. Over a total of 153 depolarizations at +10 to $+20 \mathrm{mV}$ from holding potentials of -80 and $-100 \mathrm{mV}$, the number of null sweeps was 55 , or $36 \%$. Almost all sweeps were nulls from holding potentials of $-40 \mathrm{mV}$. Cell N02B. Of a total of 43 patches with G1-type channels, voltage protocols for establishing the holding potential dependence of channel activity were applied in 28 patches.

in each plot is the best-fitting sum of exponential components (minimum number of components indicated by the maximum likelihood ratio test; see Materials and Methods). Each exponential component is shown as a dotted line. Both distributions were best fitted by the sum of two exponential components with time constants of 0.3 and $0.62 \mathrm{msec}$ for the open times and 1.34 and $3.6 \mathrm{msec}$ for the closed times, and relative areas of 56 and $44 \%$ for open times and 40 and $60 \%$ for closed times. The fastest time constant for the open times is poorly resolved. Cell N02B. Average time constants of the exponentials components best fitting open and closed time distributions at $+20 \mathrm{mV}$ from four patches with a single G1-type channel were $0.31 \pm 0.03$ and $0.77 \pm 0.06 \mathrm{msec}$ (open times) and $1.01 \pm 0.1$ and $3.8 \pm 0.24 \mathrm{msec}$ (closed times), with relative areas of 76 and $24 \pm 6 \%$ and 40 and $60 \pm 4 \%$, respectively. 
$\mathbf{a}$

$-30 \mathrm{mV}$

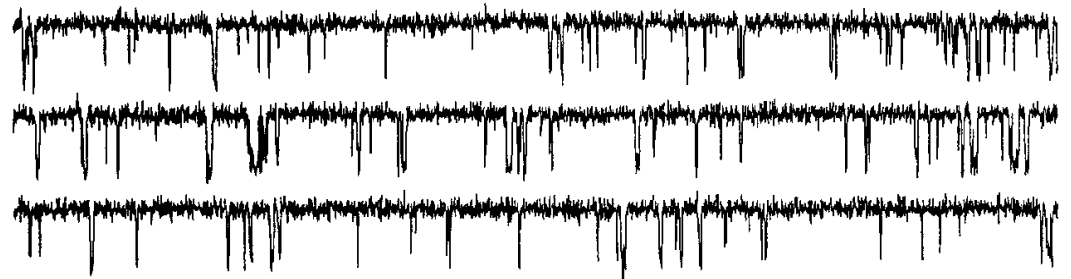

$-20 \mathrm{mV}$

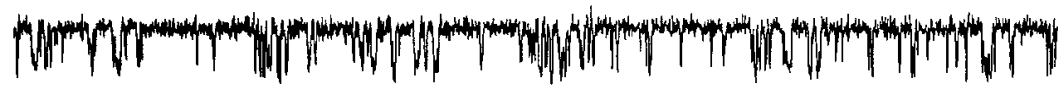

(F)
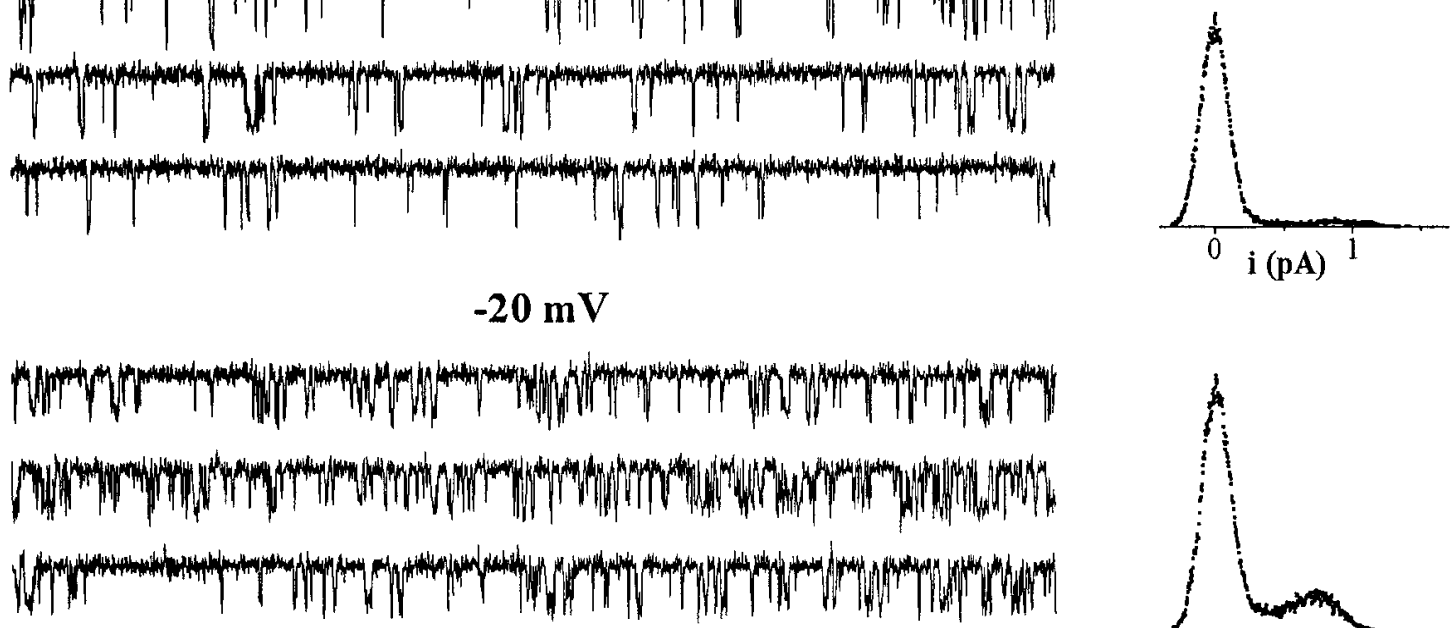

$-10 \mathrm{mV}$

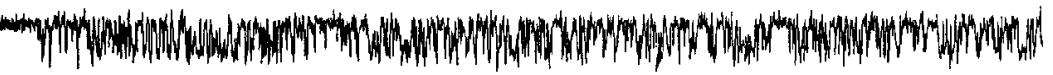

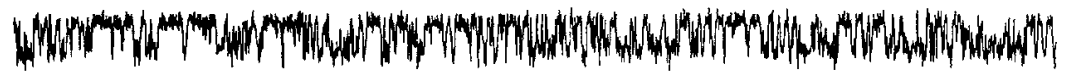

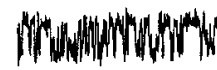
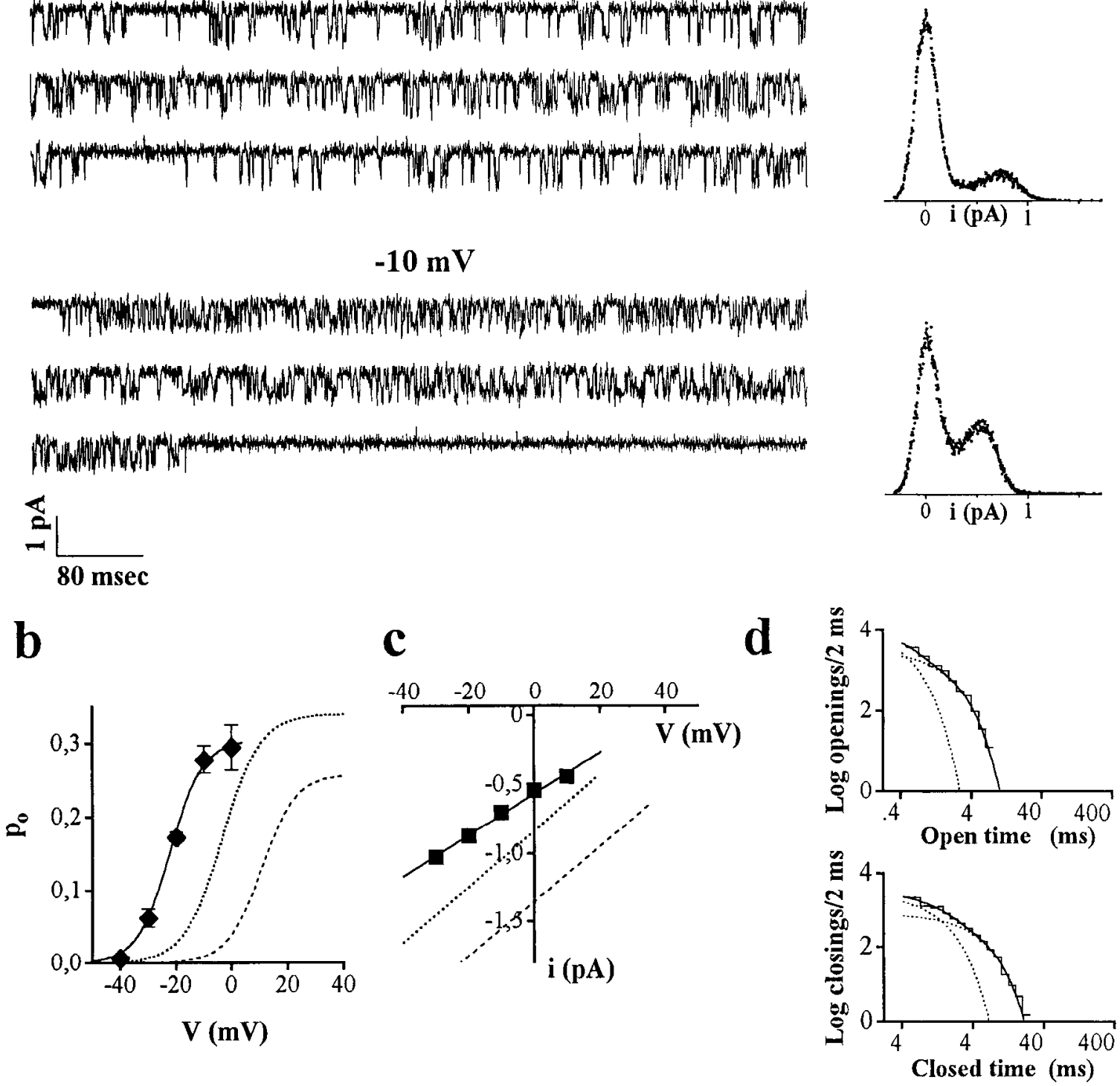

Figure 3. Conductance and activation properties of $\mathrm{G} 2$-type $\mathrm{Ca}^{2+}$ channels in cerebellar granule cells. $a$, Cell-attached recordings with 90 mM $\mathrm{Ba}^{2+}$ as charge carrier from a patch containing a single $\mathrm{G} 2$-type channel. Three representative current traces at $-30,-20$, and $-10 \mathrm{mV}$ are shown together with the normalized current amplitude histograms from all traces with activity at each $V$. Recording protocol as in Figure $1 a$, but holding potential $=-100 \mathrm{mV}$. Cell N02B. $b$, Voltage dependence of the open probability, $p_{o}$, of G2-type Ca ${ }^{2+}$ channels. Open probability values are averages from different patches $(n=4$ at $-20,-10$, and $0 \mathrm{mV} ; n=3$ at $-30 \mathrm{mV})$. For each patch, $p_{o}$ values were obtained as in Figure 1 . The data points are fitted by a Boltzmann distribution with $z=4.35, V_{1 / 2}=-22.2 \mathrm{mV}$, and $p_{o, \max }=0.305$. The dashed and dotted curves are the Boltzmann distributions for G1-type and G3-type calcium channels, respectively. $c$, Unitary current-voltage relation of G2-type calcium channels. Unitary current values are averages from five different patches (SEs are smaller than the symbol size). For each patch, values of $i$ at a given voltage are averages of many measurements on well-resolved openings at the prevailing current level. The dashed and dotted line represent the $i-V$ relations for G1-and G3-type $\mathrm{Ca}^{2+}$ channels, respectively. $d$, Log-log plots of the open and closed time distributions of a single G2-type channel. $V=-10$ $\mathrm{mV}$. Both distributions were best fitted by the sum of two exponential components with time constants of 0.29 and 1.26 msec for the open times 
$\mathbf{a}$
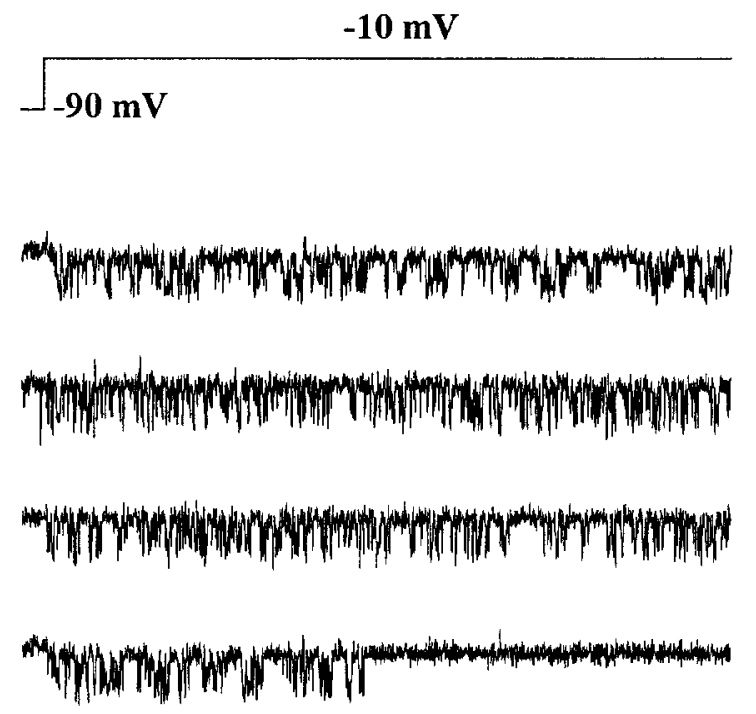

b
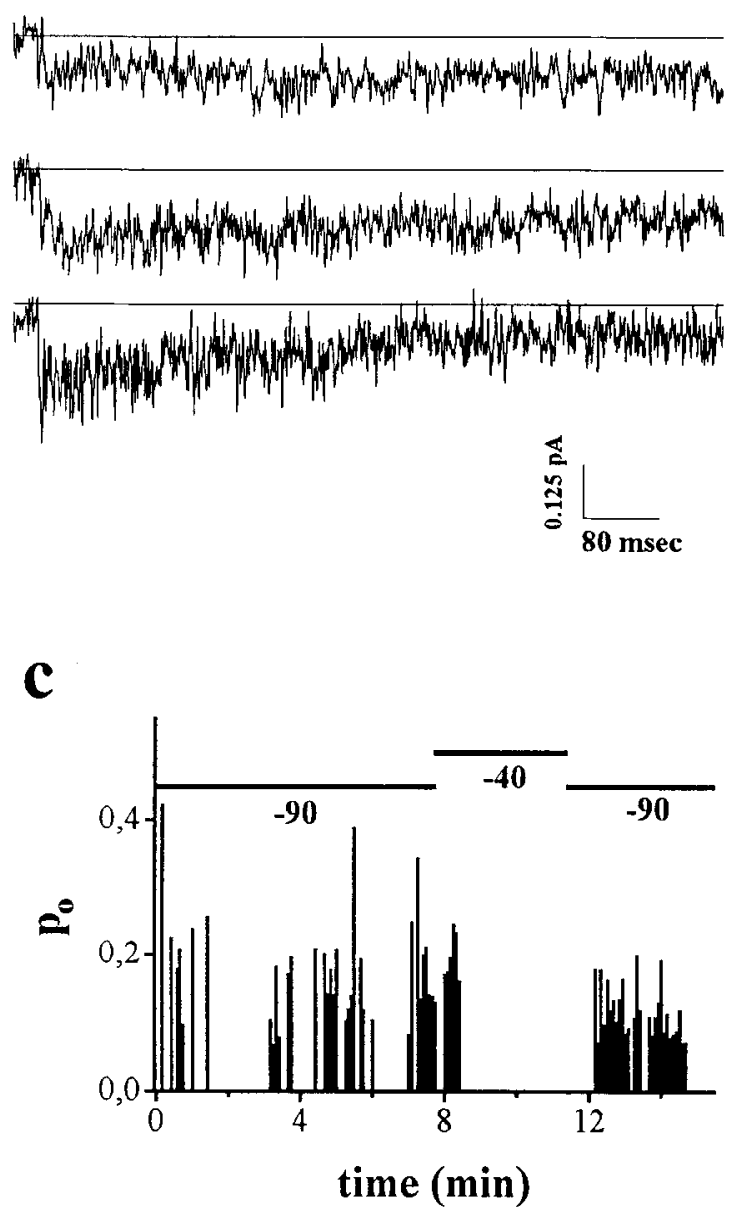

Figure 4. Inactivation properties of G2-type $\mathrm{Ca}^{2+}$ channels. $a$, Cell-attached recordings with $90 \mathrm{~mm} \mathrm{Ba}^{2+}$ as charge carrier from a patch containing a single G2-type channel. Depolarizations were $720 \mathrm{msec}$ long and were delivered every $4 \mathrm{sec}$ from holding potentials of $-90 \mathrm{mV}$. Records were sampled and filtered at 5 and $1 \mathrm{kHz}$, respectively. Five current traces (calibration: $1 \mathrm{pA}, 80 \mathrm{msec}$ ) are shown together with the ensemble average current from all sweeps with activity at $-10 \mathrm{mV}(n=28$; calibration: $0.125 \mathrm{pA}, 80 \mathrm{msec})$. The fraction of inactivating active sweeps was $39 \%$ (11 of 28). Cell C12C. $b$, Ensemble averages of single-channel currents at different voltages. Test potentials, from top to bottom trace: -20 , -10 , and $+10 \mathrm{mV}$, respectively. Average currents at $-10(n=36)$ and $+10 \mathrm{mV}(n=17)$ are from the same patch, which contained two G2-type channels (cell N73B), while the average current at $-20 \mathrm{mV}(n=77)$ is from a different patch with at least three G2-type channels (cell N03A). At each voltage, only sweeps with activity were averaged. The average fraction of inactivating active sweeps of G2-type channels in different patches was $19 \pm 2 \%$ at -20 to $-30 \mathrm{mV}(n=4), 32 \pm 2 \%$ at $-10 \mathrm{mV}(n=3)$, and $46 \pm 6 \%$ at $0-10 \mathrm{mV}(n=3)$. $c$, Holding potential dependence of the open probability of a single G2-type channel. Vertical bars in the $p_{o}$ versus time plot represent the channel open probability in successive depolarizations delivered every $4 \mathrm{sec}$. During the experiment the holding potential was changed as indicated below the horizontal bars. Test potential was most of the time at $-10 \mathrm{mV}$; in the remaining time it varied between -30 and $+10 \mathrm{mV}$. Over a total of 144 depolarizations from $-90 \mathrm{mV}$, the number of null sweeps were 59 , or $41 \%$. The clustering in time of null sweeps was typical of $\mathrm{G} 2$-type channels. Cell $\mathrm{Cl} 2 \mathrm{C}$. Of a total of 36 patches with G2-type channels, voltage protocols for establishing the holding potential dependence of channel activity were applied in 21 patches.

Figure $4 c$ shows that G2-type calcium channels, like G1-type channels, were completely inactivated at a holding potential of $-40 \mathrm{mV}$. Actually steady-state inactivation of G2-type channels seemed to occur at more negative voltages than for G1-type channels, since it was almost completc alrcady at holding potentials of $-60 \mathrm{mV}$ (not shown). Moreover, at holding potentials of -90 to $-100 \mathrm{mV}$, single G2-type channels gave rise to a higher number of null sweeps (average, $66 \pm 6 \% ; n=6$ ) with respect to single $\mathrm{G} 1$-type channels. The clustering of null sweeps evident in Figure $4 c$, giving rise to long periods of channel inactivity even at negative holding potentials, was typical of G2-type channels.

G2-type calcium channels were observed in $23 \%$ of patches from neurons kept in culture for 6-11 d (28 of 121 patches),

and 0.86 and $3.2 \mathrm{msec}$ for the closed times, and relative areas of 46 and $54 \%$ for open times and 48 and $52 \%$ for closed times. Cell N02B. Average time constants of the exponentials components best fitting open and closed time distributions at $-10 \mathrm{mV}$ from four patches with a single $\mathrm{G} 2$-type channel were $0.5 \pm 0.09$ and $1.28 \pm 0.06 \mathrm{msec}$ (open times) and $1.02 \pm 0.22$ and $4.03 \pm 0.48$ msec (closed times), with relative areas of 61 and $39 \pm 10 \%$ and 46 and $54 \pm 5 \%$, respectively. 
a

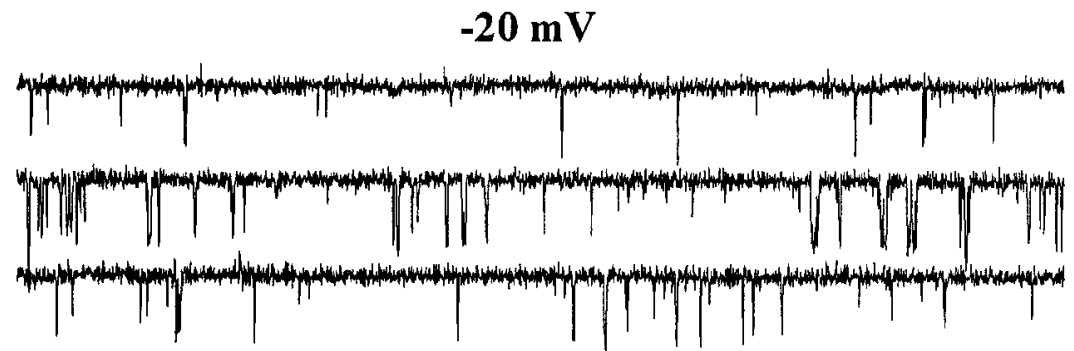

$-10 \mathrm{mV}$
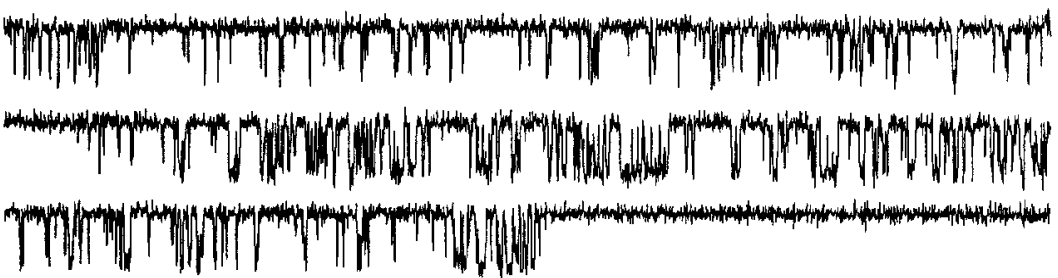

$0 \mathrm{mV}$
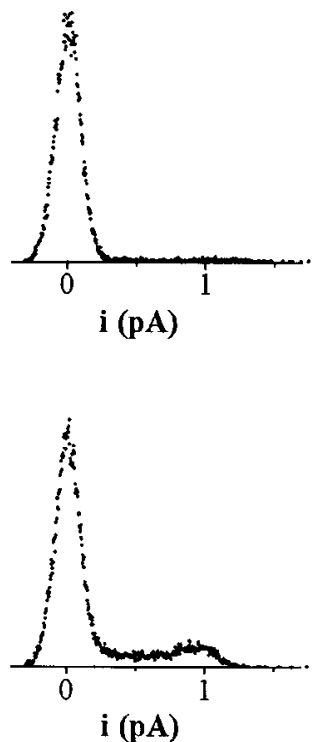

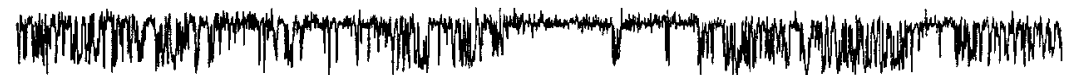

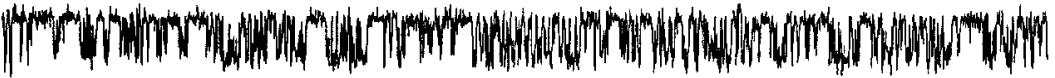

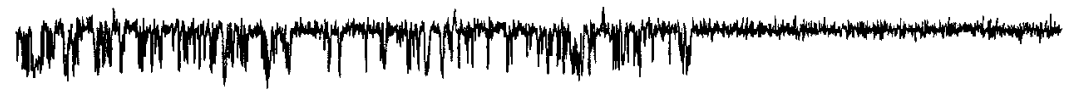

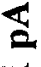

80 msec

b

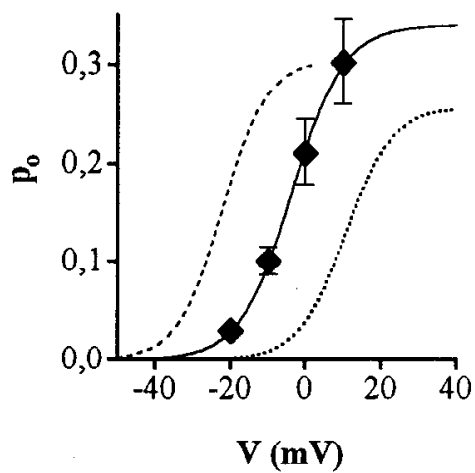

c

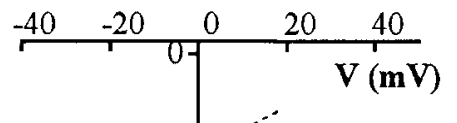

d

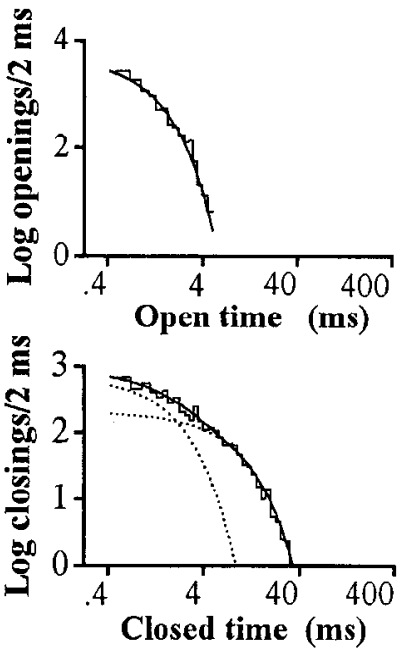

Figure 5. Conductance and activation properties of G3-type $\mathrm{Ca}^{2+}$ channels in cerebellar granule cells. $a$, Cell-attached recordings with 90 mM $\mathrm{Ba}^{2+}$ as charge carrier from a patch containing two G3-type channels. Three representative current traces at $-20,-10$, and $0 \mathrm{mV}$ are shown together with the normalized current amplitude histograms from all traces with activity at each $V$. Recording protocol as in Figure $1 a$, but holding potential $=-90 \mathrm{mV}$. Cell N46C. $b$, Voltage dependence of the open probability, $p_{o}$, of G3-type $\mathrm{Ca}^{2+}$ channels. Open probability values are averages from different patches $(n=5$ at -20 and $-10 \mathrm{mV} ; n=4$ at 0 and $10 \mathrm{mV})$. For each patch, $p_{o}$ values were obtained as in Figure 1 . The data points are fitted by a Boltzmann distribution with $z=3.78, V_{1 / 2}=-3.7 \mathrm{mV}$, and $p_{o, \max }=0.34$. The dashed and dotted curves are the Boltzmann distributions for G2-type and G1-type calcium channels, respectively. $c$, Unitary current-voltage relation of G3-type calcium channels. Unitary current values are averages from 13 different patches (SEs are smaller than the symbol size). For each patch, values of $i$ at a given voltage are averages of many measurements on well-resolved openings at the prevailing current level. The dashed and dotted line represent the $i-V$ relations for G2- and G1type $\mathrm{Ca}^{2+}$ channels, respectively. $d, \mathrm{Log}-\log$ plots of the open and closed time distributions of a single G3-type channel in the low $p_{o}$ mode. $V=$ $0 \mathrm{mV}$. The open time distribution was best fitted by a single exponential component with time constant of 0.69 msec. The closed time distribution was best fitted by the sum of two exponential components with time constants of 1.32 and $6.52 \mathrm{msec}$ and relative areas of 42 and $58 \%$. Cell C05D. 
and only in $13 \%$ of patches ( 8 of 61 ) from neurons kept in culture for 1-5 d. In different granule cell preparations there appeared to be a large variability in the fraction of patches with G2-type channels.

In two of a total of 36 patches with G2-type activity, we observed calcium channels with activation properties and unitary currents like those in Figure 3, but with steady-state inactivation occurring at more positive voltages than for typical G2-type channels, since they did not inactivate when the holding potential was changed to $-40 \mathrm{mV}$. The same considerations made under the preceding heading for the minorities of $\mathrm{Ca}^{2+}$ channels that did not completely fit into the category of G1type channcls also hold for the classification of these channcls into the G2-type category.

\section{G3-type calcium channels}

Figure $5 a$ shows the unitary activity of a G3-type calcium channel in response to 720 -msec-long test depolarizations to -20 , -10 , and $0 \mathrm{mV}$, and the corresponding amplitude histograms. The channel open probability increased almost 10 times (from 0.034 to 0.327 ) when the membrane potential was changed from -20 to $0 \mathrm{mV}$. Figure $5 b$ shows that G3-type calcium channels start to activate around $-30 \mathrm{mV}$, and reach $50 \%$ of maximal $p_{o}$ at a voltage $(-4 \mathrm{mV})$ where activation is almost maximal for G2-type channels and is around threshold for G1-type calcium channels.

The representative traces in Figure $5 a$ show that G3-type channels can exhibit two different modes of activity, a mode characterized by low $p_{o}$ and short mean open time (e.g., first trace at $-10 \mathrm{mV}$ and third trace at $0 \mathrm{mV}$ ) and another mode characterized by higher $p_{0}$ and longer mean open time (e.g., second traces at -10 and $0 \mathrm{mV}$ ). The variability in the relative frequency of appearance of the two modes in different patches accounts for the large scatter in average $p_{o}$ values at a given voltage in Figure $5 b$. Figure $5 d$ (see legend) shows the open and closed time distributions of a G3-type channel that was constantly in the low $p_{o}$ mode. Average open time duration at 0 $\mathrm{mV}$ obtained from three patches where the low $p_{0}$ mode largely prevailed was $0.99 \pm 0.01 \mathrm{msec}$, a value intermediate between the average open time durations of G1 - and G2-type $\mathrm{Ca}^{2+}$ channels. The average open time duration of the high $p_{o}$ mode in Figure $5 a$ was $1.66 \mathrm{msec}$.

The average single-channel conductance of G3-type calcium channels was $20.2 \pm 0.43 \mathrm{pS}(n=13$, with a unitary singlechannel current $i=0.84 \pm 0.01$ at $0 \mathrm{mV}$ ). The $i-V$ plot in Figure $5 c$, obtained by averaging unitary current amplitudes, has a slope conductance of $20.5 \mathrm{pS}$. Figure $5 c$ shows that, although G3- and G1-type calcium channels have similar conductances, they can be easily distinguished on the basis of the large difference in unitary currents at any voltage. Different single-channel currents with similar slope conductance can be due to different selectivities of G1- and G3-type channels for $\mathrm{Ba}^{2+}$ with respect to $\mathrm{K}^{+}$ and/or to different energy profiles for $\mathrm{Ba}^{2+}$ ions within the two pores. Given the limited range of voltages in which we could accurately measure the single-channel currents, our data do not allow an extrapolation of the reversal potential and therefore do not allow a discrimination between the different interpretations. Like G2-type channels (but less frequently), G3-type channels showed occasional openings to slightly lower (and also higher) current levels.

Figure 6 shows the inactivation properties of G3-type channels. Like $G 1$ and $G 2$ types, G3-type calcium channels were completely inactivated at a holding potential of $-40 \mathrm{mV}$ (Fig. $6 b$ ). At holding potentials of -90 to $-100 \mathrm{mV}$, single G3-type channels, like G2-type channels, gave rise to a large number of null sweeps (average, $70 \pm 2 \% ; n=4$ ), which were usually clustered together.

G3-type calcium channels were observed in $14 \%$ of patches from neurons kept in culturc for 6-11 d (18 of 126 patches) and only in $5 \%$ of patches ( 3 of 60 ) from neurons kept in culture for 1-5 d. As for G2-type channels, in different granule cell preparations there appeared to be a large variability in the fraction of patches containing G3-type channels.

\section{Pharmacology of G1-, G2-, and G3-type $\mathrm{Ca}^{2+}$ channels}

Figure 7 shows that all three G1-, G2-, and G3-type $\mathrm{Ca}^{2}$ channels were insensitive to the dihydropyridine agonist $(+)-(S)$ 202-791 and were not blocked irreversibly by the toxin $\omega$-CgTxGVIA. Since G-type channels run down in excised patches, establishing their individual sensitivity (in cell-attached patches) to the membrane-impermeable peptide $\omega$-CgTx-GVIA is not straightforward. As an additional problem, binding of $\omega$-CgTxGVIA to $\mathrm{N}$-type $\mathrm{Ca}^{2+}$ channels is known to be inhibited by high divalent ion concentrations (McCleskey et al., 1987).

We have used human neuroblastoma IMR32 cells, which express predominantly $\omega$-CgTx-sensitive $\mathrm{N}$-type $\mathrm{Ca}^{2+}$ channels (Carbone et al., 1990), to establish an experimental protocol effective in blocking single $\mathrm{N}$-type $\mathrm{Ca}^{2+}$ channels in cell-attached patches. On IMR 32 cells, kept in culture for 7-14 d after differentiation, we recorded single DHP-insensitive $\mathrm{Ca}^{2+}$ channels in $25 \%$ of patches ( 17 of 69 patches) in control conditions. The same channels were not observed in any of the 70 cell-attached patches obtained after incubation of the cells for at least $10 \mathrm{~min}$ with $2.3 \mu \mathrm{M} \omega-\mathrm{CgTx}$-GVIA in the $140 \mathrm{~mm}$ potassium gluconate divalent-free bath recording solution. We concluded that, once bound, the rate of unbinding of $\omega$-CgTx-GVIA from N-type channels in IMR 32 cells was sufficiently slow to allow detection of channel block in cell-attached recordings with $90 \mathrm{mM} \mathrm{Ba}{ }^{2+}$ in the pipette.

To establish the effect of $\omega$-CgTx-GVIA on the individual G-type channels of cerebellar granule cells, in addition to incubating the neurons with $\omega$-CgTx-GVIA in the recording divalent-free bath solution, usually we also added $2.3 \mu \mathrm{M}$ toxin to the pipette solution. As shown by the single-channel current amplitude histograms and traces in Figure 7, activity of all three G1-, G2-, and G3-type $\mathrm{Ca}^{2+}$ channels was indistinguishable with or without $\omega$-CgTx-GVIA, and also with or without $(+)-(S)$ 202-791. Also, the unitary activity of the three different types of $\mathrm{Ca}^{2+}$ channels that did not completely fit into any category, mentioned under the preceding headings, was unaffected by either $\omega$-CgTx-GVIA or (+)-(S)-202-791.

Judging from their frequency of observation in cell-attached

\section{$\leftarrow$}

Average time constants of the exponential components best fitting open and closed time distributions at $0 \mathrm{mV}$ from three patches with a G3-type channel in the low $p_{o}$ mode were $0.63 \pm 0.06 \mathrm{msec}$ (open times) and $1.5 \pm 0.24$ and $6.84 \pm 0.51 \mathrm{msec}$ (closed times; relative areas: 48 and $52 \pm$ $4 \%)$. In the patch in $a$ the high $p_{o}$ mode was frequent, and accordingly two exponential components with time constants of 0.77 and 1.94 msec (relative amplitudes, $77 \%$ and $23 \%$, respectively) were needed to best fit the open time distribution at $0 \mathrm{mV}$ (not shown). 
$\mathbf{a}$

$\sqrt{-90 \mathrm{mV}}$

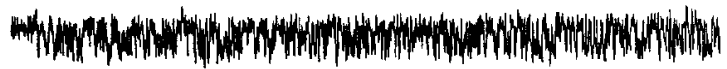

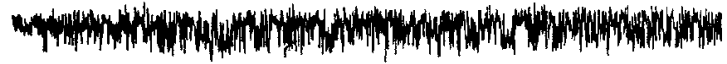

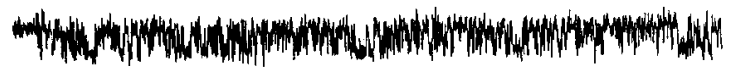

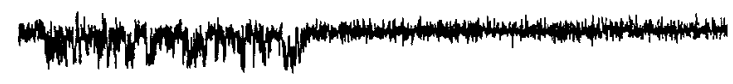

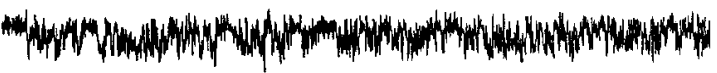
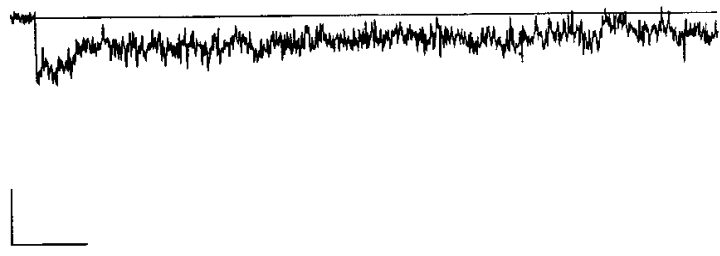

b

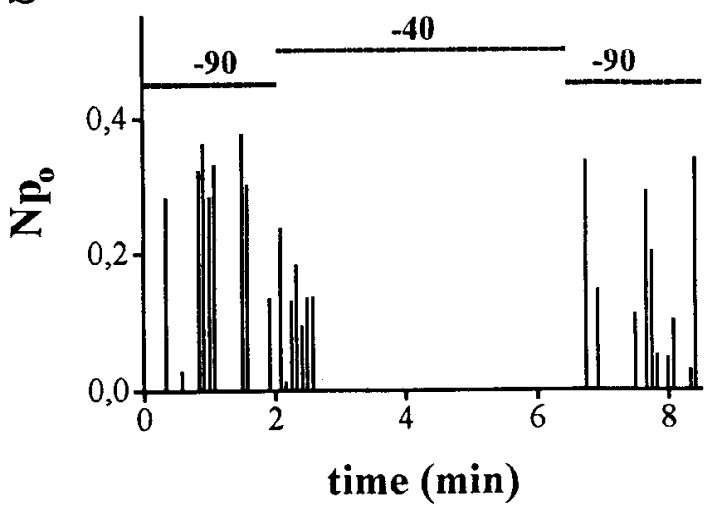

Figure 6. Inactivation properties of G3-type $\mathrm{Ca}^{2+}$ channels. $a$, Cellattached recordings with $90 \mathrm{~mm} \mathrm{Ba}{ }^{21}$ as charge carrier from a patch containing two G3-type channels. Depolarizations were $720 \mathrm{msec}$ long and were delivered every $4 \mathrm{sec}$ from holding potentials of $-90 \mathrm{mV}$. Five current traces (calibration: $1 \mathrm{pA}, 80 \mathrm{msec}$ ) are shown together with the ensemble average current from all sweeps with activity at $+20 \mathrm{mV}$ ( $n=36$; calibration: $0.175 \mathrm{pA}, 80 \mathrm{msec}$ ). The fraction of inactivating active sweeps was $26 \%$ (10 of 38). Cell N46C. $b$. Holding potential dependence of the open probability of G3-type channels. Vertical bars in the $p_{o}$ versus time plot represent the channel open probability in successive depolarizations at $+20 \mathrm{mV}$ delivered every $4 \mathrm{sec}$. During patches, G1-, G2-, and G3-type channels, together with the previously characterized multiple L-type channels (Forti and Pietrobon, 1993), constitute the large majority of $\mathrm{Ca}^{2+}$ channels of cerebellar granule cell bodies in our cultures. This conclusion is consistent with our whole-cell $\mathrm{Ca}^{2+}$ current measurements, showing that $2.3 \mu \mathrm{M} \omega$-CgTx-GVIA inhibited only $15 \pm 3 \%$ ( $n$ $=7$ ) of the $\mathrm{Ca}^{2+}$ current, elicited with depolarizations to -10 $\mathrm{mV}$ from holding potentials of $-100 \mathrm{mV}$ in granule cells kept in culture for 6-8 d, and that such inhibition was fully reversible (see lower left panel in Fig. 7).

\section{Discussion}

Our data show that three novel types of voltage-dependent $\mathrm{Ca}^{2+}$ channels resistant to DHPs and $\omega$-CgTx $(G 1, G 2$, and $G 3)$ are coexpressed in rat cerebellar granule cells in primary culture. These three classes of $\mathrm{Ca}^{2+}$ channels have different activation thresholds ( $-40 \mathrm{mV}$ for $\mathrm{G} 2,-30 \mathrm{mV}$ for $\mathrm{G} 3$, and $-10 \mathrm{mV}$ for $\mathrm{G} 1$, with $90 \mathrm{~mm} \mathrm{Ba}^{2+}$ as charge carrier), different mean open times ( $1.2 \mathrm{msec}$ for $\mathrm{G} 2,1 \mathrm{msec}$ for $\mathrm{G} 3$, and $0.8 \mathrm{msec}$ for $\mathrm{G} 1$ ), and different single-channel currents (average values at $0 \mathrm{mV}$ : $0.5 \mathrm{pA}$ for $\mathrm{G} 2,0.8 \mathrm{pA}$ for $\mathrm{G} 3$, and $1.4 \mathrm{pA}$ for $\mathrm{G} 1$ ). G1-type and G3-type channels have similar 20-21 pS unitary conductance, while G2-type channels have a lower conductance of $15 \mathrm{pS}$. G1-, G2-, and G3-type $\mathrm{Ca}^{2+}$ channels have similar inactivation properties. Their steady-state inactivation occurs at relatively negative voltages (over the range of -80 to $-40 \mathrm{mV}$ for $\mathrm{Gl}$ and over an even more negative range for G2 and G3), and the three channels produce a high number of nulls even at very negative holding potentials. They show both inactivating and noninactivating behavior during long depolarizations, producing ensemble average currents with both a sustained and a decaying component.

Many of the functional properties of G1-, G2-, and G3-type channels are only subtly different from those of $\mathrm{N}$-type channels described in different neuronal preparations (Nowycky et al., 1985; Plummer et al., 1989; Williams et al., 1992b; Fujita et al., 1993). However, if we consider as a defining characteristic of N-type channels their high-affinity block by $\omega$-CgTx-GVIA, G1-, G2-, and G3-type channels are not N-type channels, because they are not inhibited irreversibly by $\omega-\mathrm{CgTx}$. On the other hand, the functional properties of Gl-, G2-, and G3-type channels are significantly different from those of P-type channels observed in cerebellar Purkinje cells. Stcady-state inactivation of the three DHP- and $\omega-\mathrm{CgTx}$-insensitive $\mathrm{Ca}^{2+}$ channels of cerebellar granule cells is complete at voltages $(-40$ to -60 $\mathrm{mV}$ ) where steady-state inactivation of P-type channels is negligible (Regan, 1991; Usowicz et al., 1992). Moreover, P-type channels do not show a relatively fast inactivating component during long depolarizations (Regan, 1991; Usowicz et al., 1992). Three different unitary conductances were observed also in Purkinje cells, where, however, it was not possible to establish whether they originated from different conductance states of the same channel or from different channel subtypes (Usowicz et

the experiment the holding potential was changed as indicated below the horizontal bars. The patch contained two G3-type channels but overlapping openings were seen in only one depolarization over a total of 97 depolarizations at +10 to $+20 \mathrm{mV}, 58 \%$ of which were nulls. Cell $\mathrm{N} 46 \mathrm{C}$. Of a total of 21 patches with G3-type channels, voltage protocols for establishing the holding potential dependence of channel activity were applied in 15 patches. 
Control

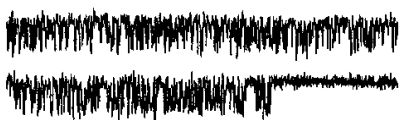

(+)-(S)-202-791

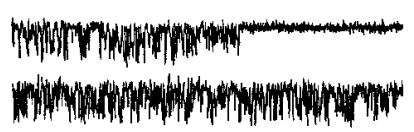

$\omega-\operatorname{CgTx}$

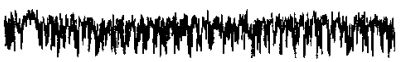
Hond

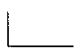

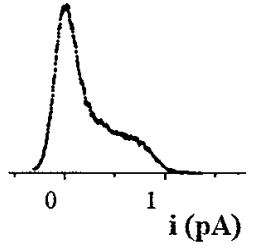
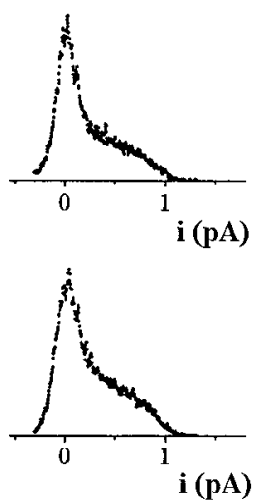

G3 $-10 \mathrm{mV}$

Control

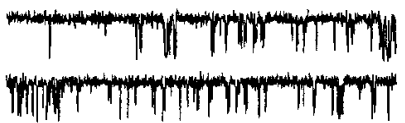

(+)-(S)-202-791

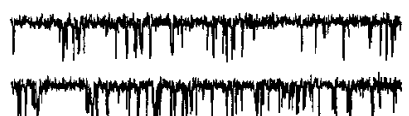

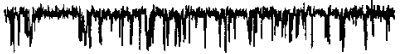

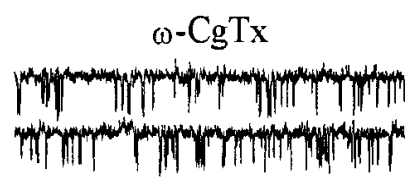

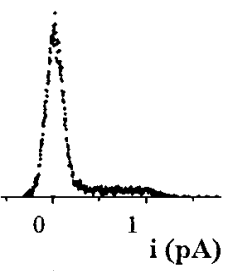
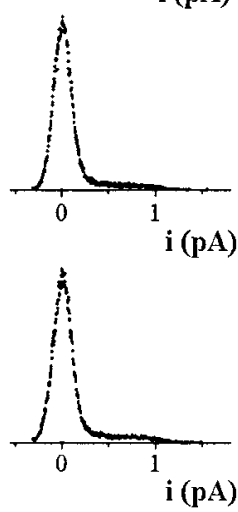

Control

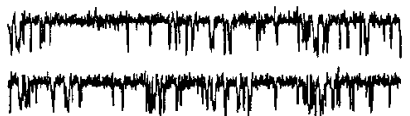

(+)-(S)-202-791

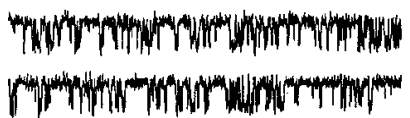

$\omega-\operatorname{CgTx}$

monthy

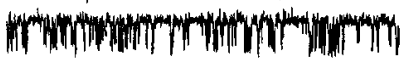
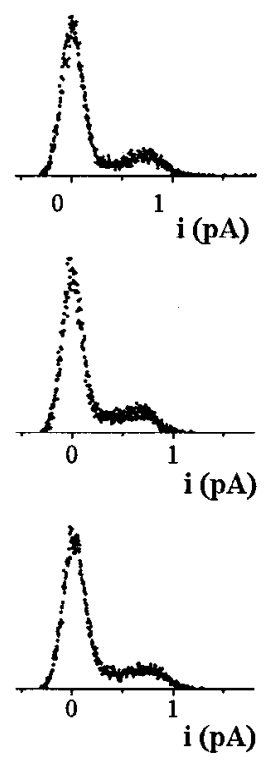

\section{whole cell}
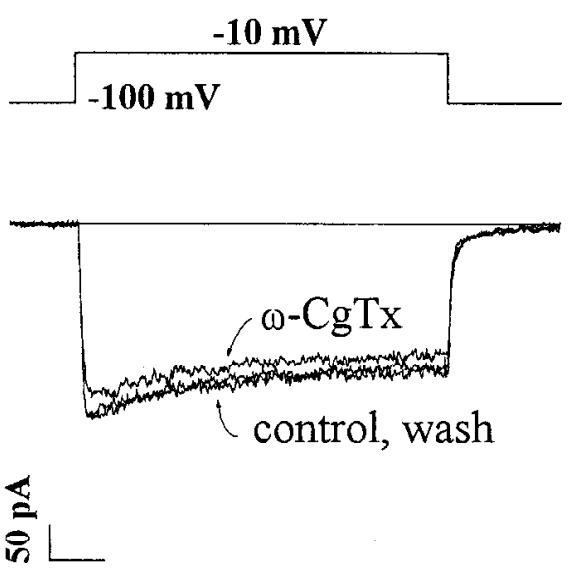

$20 \mathrm{msec}$

Figure 7. Pharmacology of G1-, G2-, and G3-type $\mathrm{Ca}^{2+}$ channels. Shown are cell-attached recordings with $90 \mathrm{mM} \mathrm{Ba}^{2+}$ as charge carrier: representative current traces and normalized current amplitude histograms from all traces with activity of single G1-type channels at $+20 \mathrm{mV}$, G2-type channels at $-20 \mathrm{mV}$ and G3-type channels at -10 mV. Controls, Recording conditions and cells as in Figures 1, 3, and 5 for G1-, G2-, and G3-type $\mathrm{Ca}^{2+}$ channels, respectively. In the case of G3-type channels the control amplitude histogram (cell N46C) was obtained only from traces with the channel in the low $p_{o}$ mode of activity, to allow a suitable comparison with the two patches in the presence of either $(+)-(S)-202-$ 791 or $\omega$-CgTx shown in the figure (cells N56B and N85A), where the low $p_{o}$ mode of activity largely prevailed. $(+)-(S)-202-791, \mathrm{Recordings}$ in the presence of $1 \mu \mathrm{M}(+)-(S)-202-791$ in the bath. $G 1$, cell C14A; $G 2$, cell N57D; $G 3$, cell N56B. In the presence of DHP agonist, G1-type Ca ${ }^{2+}$ channels were observed in 10 of 29 patches, G2-type channels in 5 of 29 patches, and G3-type channels in 4 of 30 patches (where identification was certain). $\omega-C g T x$, Recordings in the presence of $2.3 \mu \mathrm{M} \omega$-CgTx-GVIA both in the pipette and in the bath, after incubation of the granule cells with the toxin in the bath solution for at least $10 \mathrm{~min}$. $G 1$, cell N85B; $G 2$, cell $\mathrm{C} 12 \mathrm{C}$; $G 3$, cell N85A. In the presence of $\omega$-CgTx, G1-type Ca2+ channels were observed in 13 of 44 patches, G2 type in 9 of 53 patches, and G3 type in 5 of 54 patches (with certain identification). Most likely, the large variability in the frequency of observation of G2- and G3-type channels in different granule cell preparations can account for the small reduction in the fraction of patches with G2- and G3-type channels observed in the presence of agonist or $\omega$-CgTx-GVIA with respect to controls. Whole cell, Whole-cell recordings with $5 \mathrm{mM} \mathrm{Ba}^{2+}$ as charge carrier. Representative current traces recorded before (control) and after ( $\omega$-CgTx) perfusion with $2.3 \mu \mathrm{M} \omega-\mathrm{CgTx}$-GVIA in the bath solution are shown together with a trace after reperfusion with control solution (wash). Cell C48D. Depolarizations were $160 \mathrm{msec}$ long and were delivered every $8 \mathrm{sec}$ from holding potentials of $-100 \mathrm{mV}$. Records were sampled and filtered at 5 and $1 \mathrm{kHz}$, respectively. Whole-cell $\mathrm{Ca}^{2+}$ current was completely inhibited by $20 \mu \mathrm{M} \mathrm{Cd} \mathrm{C}^{2+}$ (not shown). 
al., 1992). The functional properties of the $19 \mathrm{pS}$ conductance channel described in Purkinje cells are quite similar to those of the minority of channels in our cerebellar granule cells with G1type activation properties, but with steady-state inactivation at much more positive voltages than that of typical Gl channels.

For the time being, if we consider as a defining characteristic of P-type channels their specific block by $\omega$-Aga-IVA (Mintz et al., 1992a,b), it remains unknown if (and/or which of) the DHPand $\omega-\mathrm{CgTx}$-insensitive channels of our cerebellar granule cells belong to the category of $\mathrm{Ca}^{2+}$ channels resistant to all specific blockers of L-, N-, and P-type channels or if they are functionally different subtypes of $\omega$-Aga-IVA-sensitive P-type channels. The functional properties of $\mathrm{G}$ 2-type $\mathrm{Ca}^{2+}$ channels, especially their low threshold for activation $\left(-40 \mathrm{mV}\right.$ with $\left.90 \mathrm{~mm} \mathrm{Ba}{ }^{2+}\right)$ and their inactivation properties, appear quite similar to those of the channels with a pharmacological profile distinct from that of L-, N-, and P-type channels, which are produced in oocytes after nuclear injection of $\alpha_{1}-\mathrm{E}$ (Soong et al., 1993). Interestingly, $\alpha_{1}-\mathrm{E}$ appears to be expressed through the rat CNS and to be highly expressed in the granule layer of rat cerebellar cortex (Soong et al., 1993). A comparison between the properties of G1-type and G3-type channels with those of the channels produced in oocytes by injection of $\alpha_{1}$-A leads to uncertain conclusions, because there are contradictory reports on the functional properties of recombinant $\alpha_{1}-\mathrm{A}$ (BI), especially its inactivation properties (Mori et al., 1991; Ellinor et al., 1993; Sather et al., 1993), and the latter properties vary considerably depending on the type of $\beta$ subunit coexpressed with $\alpha_{1}$ (Ellinor et al., 1993; Sather et al., 1993). We feel that at the moment it cannot be excluded that G1- (and/or G3-) type channels are encoded by a class $\mathrm{A}$ gene. It will be interesting to establish the sensitivity of our channels to $\omega$-Aga-IVA and $\omega$-CTx-MVIIC, a new peptide toxin isolated from Conus magus, which has been shown to inhibit recombinant $\alpha_{1}$-A channels and also a component of $\mathrm{Ca}^{2+}$ current resistant to DHPs, $\omega$-CgTx-GVIA, and low concentrations of $\omega$-Aga-IVA in cerebellar granule cells and other CNS neurons (Hillyard et al., 1992; Randall et al., 1993; Sather et al., 1993; Swartz et al., 1993).

It is important to note that on the basis of whole-cell measurements of macroscopic $\mathrm{Ca}^{2+}$ current it would be impossible to dissect G1-, G2-, and G3-type channels, because they have similar inactivation properties and their threshold for activation varies gradually along the voltage axis. The threshold for activation of G2-type channels is so low (taking into account the positive voltage shift probably induced by the high $\mathrm{Ba}^{2+}$ concentration) that it becomes problematic to classify them as highvoltage-activated (HVA) $\mathrm{Ca}^{2+}$ channels. On the other hand, their functional properties are so different from those of classical T-type channels (Swandulla et al., 1991) that a classification into the category of low-voltage-activated (LVA) $\mathrm{Ca}^{2+}$ channels appears even more problematic. As suggested by our data, neuronal $\mathrm{Ca}^{2+}$ channels might best be regarded as a family of channels with activation threshold and, more in general, voltagedependent properties that range along a continuum.

Judging from the frequency of their observation in cell-attached patches, G1-, G2-, and G3-type channels, together with the previously characterized multiple L-type channels (Forti and Pietrobon, 1993), account for most of the $\mathrm{Ca}^{2+}$ channels of cerebellar granule cell bodics in our cultures. This conclusion is consistent with whole-cell $\mathrm{Ca}^{2+}$ current measurements showing that our cerebellar granule cells in primary culture for 6-8 d lack a measurable $\mathrm{N}$-type $\mathrm{Ca}^{2+}$ current component irreversibly blocked by $\omega-\mathrm{CgTx}$. Previously, both complete insensitivity of cerebellar granule cell $\mathrm{Ca}^{2+}$ current to $\omega$-CgTx (Bertolino et al., $1990)$ and various degrees of block by $\omega-\mathrm{CgTx}$ (De Waard et al., 1992; Marchetti et al., 1992; Haws et al., 1993; Pearson et al., 1993; Randall et al., 1993) have been reported. Different culture or recording conditions and/or age might account for these conflicting results (Pearson et al., 1993). Our data show clearly that expression of G1-, G2-, and G3-type channels vary very markedly with time in culture.

The fact that neurotransmission between cerebellar granule cclls and Purkinje cells also appears to be not inhibited by either DHPs or $\omega$-CgTx (Randall and Raabe, 1992; Doroshenko et al., 1993; Pocock et al., 1993; Sugimori et al., 1993) suggests that one or more of the novel voltage-dependent $\mathrm{Ca}^{2+}$ channels here described are probably critically involved in neurotransmitter release from granule cells. Moreover, a more general role of these novel channels in neurotransmitter release within the mammalian CNS seems likely, in view of the findings that only a small fraction of $\mathrm{Ca}^{2+}$ influx and glutamate release from rat brain synaptosomes is inhibited by $\omega-\mathrm{CgTx}$ and DHPs, and a large fraction, but not all, of the DHP- and $\omega$-CgTx-insensitive glutamate release is inhibited by $\omega$-Aga-IVA (Suszkiw et al., 1989; Mintz et al., 1992a; Turner et al., 1992). More recently, it has been shown that $\mathrm{Ca}^{2+}$ channels resistant to DHPs and $\omega$-CgTx-GVIA play a major role in controlling neurotransmission at a variety of CNS synapses (Luebke et al., 1993; Takahashi and Momiyama, 1993). Cholinergic transmission in mouse neuromuscular junction was found to be not affected by $\omega-\mathrm{CgTx}$, but to be largely inhibited by FTX and $\omega$-CTX-MVIIC (Uchitel et al., 1992; Bowersox et al., 1993).

\section{References}

Ahlijanian MK, Striessnig J, Catterall WA (1991) Phosphorylation of an $\alpha_{1}$-like subunit of an $\omega$-conotoxin-sensitive brain calcium channel by cAMP-dependent protein kinase and protein kinase C. J Biol Chem 266:20192-20197.

Bean BP (1989) Classes of $\mathrm{Ca}^{2+}$ channels in vertebrate cells. Annu Rev Physiol 51:367-384.

Bertolino M, Llinas RR (1992) The central role of voltage-activated and receptor-operated calcium channels in neuronal cells. Annu Rev Pharmacol Toxicol 32:399-421.

Bertolino M, Vicini S, Costa E, LLinas R (1990) Pharmacological and electrophysiological characterization of voltage-activated calcium currents in rat cerebellar granule neurons. FASEB J Abstr 4:A1202.

Biel M, Ruth P, Bosse E, Hullin R, Stuhmer W, Flockerzi V, Hofmann F (1990) Primary structure and functional expression of a high voltage activated calcium channel from rabbit lung. FEBS Lett 269: $409-412$.

Bowersox S, Ko C-P, Sugiura Y, Li CZ, Fox J, Hoffman BB, Miljanich G (1993) Omega-conopeptide SNX-230 (MVIIC) blocks calcium channels in mouse neuromuscular junction nerve terminals. Soc Neurosci Abstr 19:1478.

Carbone E, Sher E, Clementi F (1990) Ca currents in human neuroblastoma IMR 32 cells: kinetics, permeability and pharmacology. Pfluegers Arch 416:170-179.

Castellano A, Wei X, Birnbaumer L, Perez-Reyes E (1993) Cloning and expression of a neuronal calcium channel $\beta$ subunit. J Biol Chem 268:12359-12366.

Colquhoun D, Sigworth FJ (1983) Fitting and statistical analysis of single-channel records. In: Single channel recordings (Sakmann B, Neher E, eds), pp 191-264. New York: Plenum.

De Waard M, Seagar M, Feltz A, Couraud F (1992) Inositol phosphate regulation of voltage-dependent calcium channels in cerebellar granule neurons. Neuron 9:497-503.

Doroshenko PA, Woppmann A, Miljanich G, Augustine GJ (1993) Pharmacological properties and localization of calcium channel types in the cerebellar cortex. Soc Neurosci Abstr 19:1754. 
Dubel SJ, Starr TVB, Hell J, Ahlijanian MK, Enyeart JJ, Catterall WA, Snutch TP (1992) Molecular cloning of the $\alpha-1$ subunit of an $\omega$-conotoxin-sensitive calcium channel. Proc Natl Acad Sci USA 89:50585062.

Ellinor PT, Zhang J-F, Randall AD, Zhou M, Schwarz TL, Tsien RW, Horne WA (1993) Functional expression of a rapidly inactivating neuronal calcium channel. Nature 363:455-458.

Forti L, Pietrobon D (1993) Functional diversity of L-type calcium channels in rat cerebellar neurons. Neuron 10:437-450.

Fournier F, Bourinet E, Nargeot J, Charnet P (1993) c-AMP-dependent regulation of P-type calcium channels expressed in Xenopus oocytes. Pfluegers Arch 423:173-180.

Fujita Y, Mynlicff M, Dirksen R, Kim M-S, Niidome T, Nakai J, Friedrich T, Iwabe N, Miyata T, Furuichi T, Furutama D, Mikoshiba K, Mori Y, Beam KG (1993) Primary structure and functional expression of the $\omega$-conotoxin-sensitive $\mathrm{N}$-type calcium channel from rabbit brain. Neuron 10:585-598.

Hamill O, Marty A, Neher E, Sakmann B, Sigworth F (1981) Improved patch-clamp techniques for high-resolution current recording from cells and cell-free membrane patches. Pfluegers Arch 391:85-100.

Haws CM, Slesinger PA, Lansman JB (1993) Dihydropyridine- and $\omega$-conotoxin-sensitive $\mathrm{Ca}^{2+}$ currents in cerebellar neurons: persistent block of L-type channels by a PTX-sensitive G-protein. J Neurosci 13:1148-1156

Hess P (1990) $\mathrm{Ca}^{2+}$ channels in vertebrate cells. Annu Rev Neurosci 13:337-356.

Hille B (1992) Ionic channcls of excitable membranes. Sutherland, MA: Sinauer.

Hillyard DR, Monje VD, Mintz IM, Bean BP, Nadasdi L, Ramachandran J, Milijanich G, Azimi-Zoonooz A, McIntosh JM, Cruz LJ, Imperial JS, Olivera BM (1992) A new Conus peptide ligand for mammalian presynaptic $\mathrm{Ca}^{2+}$ channels. Neuron 9:69-77.

Hirning LD, Fox AP, McCleskey EW, Olivera BM, Thayer SA, Miller RJ, Tsien RW (1988) Dominant role of $\mathrm{N}$-type $\mathrm{Ca}^{2+}$ channels in evoked release of norepinephrine from sympathetic neurons. Science 239:57-61.

Horn R, Lange K (1983) Estimating kinetic constants from single channel data. Biophys J 43:207-223.

Hui A, Ellinor PT, Krizanova O, Wang J-J, Diebold RJ, Schwartz A (1991) Molecular cloning of multiple subtypes of a novel rat brain isoform of the $\alpha_{1}$ subunit of the voltage-dependent calcium channel. Neuron 7:35-44.

Hullin R, Singer-Lahat D, Freichel M, Biel M, Dascal M, Hoffmann F, Flockerzi V (1992) Calcium channel $\beta$ subunit heterogeneity: functional expression of cloned cDNA from heart, aorta and brain. EMBO J 11:885-890.

Johnston D, Williams S, Jaffe D, Gray R (1992) NMDA-receptor independent long-term potentiation. Annu Rev Physiol 54:489-505.

Kasai H, Neher E (1992) Dihydropyridine-sensitive and $\omega$-conotoxinsensitive calcium channels in a mammalian neuroblastoma-glioma cell line. J Physiol (Lond) 448:161-188.

Kullmann DM, Perkel DJ, Manabe T, Nicoll RA (1992) $\mathrm{Ca}^{2+}$ entry via postsynaptic voltage-sensitive $\mathrm{Ca}^{2+}$ channels can transiently potentiate excitatory synaptic transmission in the hippocampus. Neuron 9:1175-1183.

Levi G, Aloisi M, Ciotti M, Gallo V (1984) Autoradiographic localization and depolarization-induced release of amino acids in differentiating granule cell cultures. Brain Res 290:77-86.

Llinas RR (1988) The intrinsic electrophysiological properties of mammalian neurons: insight into central nervous system function. Science 242:1654-1664.

Luebke JI, Dunlap KD, Turner TJ (1993) Multiple calcium channel types control glutamatergic synaptic transmission in the hippocampus. Neuron 11:895-902.

Marchetti C, Usai C, Nobile M (1992) Voltage-sensitive calcium currents in rat cerebellar cells in dissociated cultures. Biophys J 61:A398.

McEnery MW, Snowman AM, Sharp AH, Adams ME, Snyder SH (1991) Purified $\omega$-conotoxin-GVIA receptor of rat brain resembles a dihydropyridine-sensitive L-type calcium channel. Proc Natl Acad Sci USA 88:11095-11099.

McKlcskcy EW, Fox AP, Feldman DH, Cruz LJ, Olivera BM, Tsien RW, Yoshikami DY (1987) $\omega$-Conotoxin: direct and persistent blockade of specific types of calcium channels in neurons but not muscle. Proc Natl Acad Sci 84:4327-4331

McManus OB, Blatz AL, Magleby KL (1987) Sampling, log binning, fitting and plotting durations of open and shut intervals from single channels and the effect of noise. Pfluegers Arch 410:530-553.

Mikami A, Imoto K, Tanabe T, Niidome T, Mori Y, Takeshima $\mathrm{H}$, Narumiya S, Numa S (1989) Primary structure and functional expression of the cardiac dihydropyridine-sensitive calcium channel. Nature 340:230-233.

Mintz IM, Venema VJ, Swiderek KM, Lee TD, Bean BP, Adams ME (1992a) P-type calcium channels blocked by the spider toxin $\omega$-AgaIVA. Nature 355:827-829.

Mintz IM, Adams ME, Bean BP (1992b) P-type calcium channels in rat central and peripheral neurons. Neuron 9:85-95.

Mori Y, Friedrich T, Kim M-S, Mikami A, Nakai J, Ruth P, Bosse E, Hofmann F, Flockerzi V, Furuichi T, Mikoshiba K, Imoto K, Tanabe $T$, Numa $\mathbf{S}$ (1991) Primary structure and functional expression from complementary DNA of a brain calcium channel. Nature 350:398402.

Niidome T, Kim M-S, Friedrich T, Mori Y (1992) Molecular cloning and characterization of a novel calcium channel from rabbit brain. FEBS Lett 308:7-13.

Nowycky MC, Fox AP, Tsien RW (1985) Three types of neuronal calcium channels with different calcium agonist sensitivity. Nature 316:440-443.

Pearson HA, Sutton KG, Scott RH, Dolphin AC (1993) $\mathrm{Ca}^{2+}$ currents in cerebellar granule neurones: role of internal $\mathrm{Mg}^{2+}$ in altering characteristics and antagonist effects. Neuropharmacology 32:1171-1183.

Perez-Reyes E, Castellano A, Kim HS, Bertrand P, Baggdstrom E, Lacerda AE, Wei X, Birnbaumer L (1992) Cloning and expression of a cardiac/brain $\beta$ subunit of the L-type calcium channel. J Biol Chem 267:1792-1797.

Plummer MR, Logothetis DE, Hess P (1989) Elementary properties and pharmacological sensitivities of calcium channels in mammalian peripheral neurons. Neuron 2:1453-1463.

Pocock JM, Cousin MA, Nicholls DG (1993) The calcium channel coupled to the exocytosis of L-glutamate from cerebellar granule cells is inhibited by the spider toxin, Aga-GI. Neuropharmacology 32: 1185-1194.

Randall AD, Wendland B, Schweizer F, Miljanich G, Adams ME, Tsien RW (1993) Fivc pharmacologically distinct high voltage-activated $\mathrm{Ca}^{2+}$ channels in cerebellar granule cells. Soc Neurosci Abstr 19:1478.

Randall RD, Raabe W (1992) A non T-, N- or L-type calcium channel mediates release of transmitter from cerebellar granule cells in tissue culture. Soc Neurosci Abstr 18:429.

Rao CR (1973) Linear statistical inference and its applications. New York: Wiley.

Regan LJ (1991) Voltage-dependent calcium currents in Purkinje cells from rat cerebellar vermis. J Neurosci 1 1:2259-2269.

Regan LJ, Sah DWY, Bean BP (1991) Ca channels in rat central and peripheral neurons: high threshold current resistant to dihydropyridine blockers and $\omega$-conotoxin. Neuron 6:269-280.

Sakamoto J, Campbell KP (1991) A monoclonal antibody to the $\beta$ subunit of the skeletal muscle dihydropyridine receptor immunoprecipitates the brain $\omega$-conotoxin GVIA receptor. J Biol Chem 266: 18914-18919.

Sather WA, Tanabe T, Zhang JF, Mori Y, Adams ME, Tsicn RW (1993) Distinctive biophysical and pharmacological properties of class A (BI) calcium channel $\alpha_{1}$ subunit. Neuron 11:291-303.

Sheng M, Greenberg ME (1990) The regulation and function of $c$-fos and other immediate early genes in the nervous system. Neuron $4: 477-$ 485 .

Sher E, Clementi F (1991) $\omega$-Conotoxin-sensitive voltage-operated calcium channels in vertebrate cells. Neuroscience 42:301-307.

Sigworth FJ, Sine SM (1987) Data transformation for improved display and fitting of single-channel dwell time histograms. Biophys J 52:1047-1054.

Singer D, Biel M, Lotan I, Flockerzi V, Hofmann F, Dascal N (1991) The roles of the subunits in the function of the calcium channel. Science 253:1553-1557.

Snutch TP, Leonard JP, Gilbert MM, Lester HA, Davidson N (1990) Rat brain expresses a heterogeneous family of calcium channels. Proc Natl Acad Sci USA 87:3391-3395.

Snutch TP, Tomlinson WJ, Leonard JP, Gilbert MM (1991) Distinct calcium channels are generated by alternative splicing and are differentially expressed in the mammalian CNS. Neuron 7:45-57.

Soong TW, Stea A, Hodson CD, Dubel SF, Vincent SR, Snutch TP 
(1993) Structure and functional expression of a member of the low voltage-activated calcium channel family. Science 260:1133-1136.

Starr TVB, Prystay W, Snutch TP (1991) Primary structure of calcium channel that is highly expressed in the rat cerebellum. Proc Natl Acad Sci USA 88:5621-5625.

Sugimori M, Cherksey B, Llinas R (1993) P-type calcium channels are responsive for transmission at the parallel and climbing fiber synapses in Purkinje cells. Soc Neurosci Abstr 19:1526.

Suszkiw JB, Murawsky MM, Shi M (1989) Further characterization of phasic calcium influx in rat cerebrocortical synaptosomes: inferences regarding calcium channel type(s) in nerve endings. J Neurochem 52:1260-1269.

Swandulla D, Carbone E, Lux HD (1991) Do calcium channel classification accounts for neuronal calcium channel diversity? Trends Neurosci 14:46-51.

Swartz KJ, Mintz IM, Boland LM, Bean BP (1993) Block of calcium channels in central and peripheral rat neurons by $\omega$-conotoxin-MVIIC. Soc Neurosci Abstr 19:1478.

Takahashi T, Momiyama A (1993) Different types of calcium channels mediate central synaptic transmission. Nature 366:156-158.

Tsien RW, Ellinor PT, Horne WA (1991) Molecular diversity of voltage-dependent $\mathrm{Ca}^{2+}$ channels. Trends Pharmacol Sci 12:349-354.

Turner TJ, Adams ME, Dunlap K (1992) Calcium channels coupled to glutamate release identified by $\omega$-Aga-IVA. Science 258:310-313.

Uchitel OD, Protti DA, Sanchez V, Cherskey BD, Sugimori M, Llinas $R$ (1992) P-type voltage-dependent calcium channel mediates pre- synaptic calcium influx and transmitter release in mammalian synapses. Proc Natl Acad Sci USA 89:3330-3333.

Usowicz MM, Sugimori M, Cherskey B, Llinas R (1992) P-type calcium channels in the somata and dendrites of adult cerebellar Purkinje cells. Neuron 9:1185-1199.

Weiss JH, Hartley DM, Koh J, Choi DW (1990) The calcium channel blocker nifedipine attenuates slow excitatory amino acid neurotoxicity. Science 247:1474-1477.

Williams ME, Feldman DH, McCue AF, Brenner R, Velicelebi G, Ellis SB, Harpold MM (1992a) Structure and functional expression of $\alpha_{1}, \alpha_{2}$, and $\beta$ subunits of a novel human neuronal calcium channel subtype. Neuron 8:71-84.

Williams ME, Brust PF, Feldman DH, Patthi S, Simerson S, Maroufi A, McCue AF, Velicelebi G, Ellis SB, Harpold MM (1992b) Structure and functional expression of an $\omega$-conotoxin-sensitive human N-type calcium channel. Science 257:389-395.

Witcher DR, De Waard M, Sakamoto J, Franzini-Armstrong C, Pragnell M, Kahl SD, Campbell KP (1993) Subunit identification and reconstitution of the $\mathrm{N}$-type $\mathrm{Ca}^{2+}$ channel complex purified from brain. Science 261:486-489.

Zhang J-F, Randall AD, Ellinor PT, Horne WA, Sather WA, Tanabe T, Schwarz TL, Tsien RW (1993) Distinctive pharmacology and kinetics of cloned neuronal $\mathrm{Ca}^{2+}$ channels and their possible counterparts in mammalian CNS neurons. Neuropharmacology 32:10751088. 